Revista de Estudios Histórico-Jurídicos

[Sección historia del derecho indiano]

XLII (Valparaíso, Chile, 2020)

[pp. 397-425]

\title{
LOS INDIOS COMO “PERSONAS MISERABLES” EN BARTOLOMÉ DE LAS CASAS: LA JURISDICCIÓN ECLESIÁSTICA COMO UN REMEDIO PARA LAS INDIAS
}

[The Indians as "personas miserables" in Bartolomé de las Casas: The Ecclesiastical Jurisdiction as a Remedy for the Indies]

\author{
Ana María Vargas del Carpio*
}

Universidad Católica San Pablo, Perú"

\section{RESUMEN}

En 1545, Bartolomé de las Casas, obispo de Chiapa, acudió por primera vez a la categoría jurídica de las personae miserabiles para amparar la tutela jurisdiccional de los indios, y ocuparse de la vista y protección de sus causas. Este trabajo presenta un análisis de los requerimientos que él hizo al presidente y a los oidores de la audiencia de los Confines en 1545, así como del contexto histórico que influyó en Las Casas para reclamar la jurisdicción eclesiástica sobre los indios. El propósito de esta investigación es exponer los aspectos del pensamiento lascasiano que configuraron sus presupuestos asociados a los indios como $\mathrm{p}$ e $\mathrm{r} s$ o $\mathrm{n}$ a $\mathrm{s}$ $\mathrm{m}$ is e rables.

\section{AbSTRACT}

In 1545, Bartolomé de las Casas, Bishop of Chiapa, appealed for the first time to the legal category of personae miserabiles in order to safeguard the jurisdictional protection of the Indians, and to take part in the hearings and defence of their legal cases. This paper presents an analysis of the requests he made to the officials of the Audiencia de los Confines in 1545, as well as of the historical context that influenced Las Casas in claiming ecclesiastical jurisdiction over the Indians. The purpose of this research is to expose the aspects of his thinking that underpinned his rationale for associating the Indians with the personas miserables.

* Profesora del Departamento de Humanidades de la Universidad Católica San Pablo, Perú. Licenciada en Historia y estudiante de Derecho. Este trabajo de investigación se ha llevado a cabo en el marco de la Maestría en Historia de la UCSP. Agradezco especialmente al Profesor Francisco Rizo-Patrón Bazo, por su valiosa asesoría, y a los Profesores Fernando Valle Rondón y Rafael Sánchez-Concha Barrios, por sus comentarios al proyecto de investigación, que han sido de mucha utilidad. Asimismo, agradezco a la Escuela de Postgrado de la UCSP por la beca parcial de estudios para seguir esta maestría. Urb. Campiña Paisajista, Quinta Vivanco s/n, Arequipa, Perú. Correo electrónico: avargas@ucsp.edu.pe.

** Abreviaturas: AGI = Archivo General de Indias; AHNE = Archivo Histórico Nacional de España. 
Explicaremos que la razón esencial de su caracterización fue que los indios eran personas miserables debido a su estado de vulnerabilidad, de opresión y desamparo, a diferencia de algunas consideraciones de autores de nuestro tiempo, que en sus caracterizaciones de los indios como personas miserables sostienen supuestos de minoridad o de incapacidad.

Palabras clave

Indios - personas miserables - indios miserables - encomienda - Bartolomé de Las Casas - desamparo - justiciajurisdicción - derecho canónico indiano.
I will argue that the essential character of his rationalization was that the Indians were personas miserables because of their state of vulnerability, oppression and abandonment, rather than, as presented in some modern analyses, that the Indians were considered personas miserables based on premises of minority and incapacity.

\section{KeYWORDS}

Indians - Personas Miserables - Indian Miserables - Encomienda - Bartolomé de Las Casas - Abandonment - Justice - Jurisdiction - Indian Canon Law.

RECIBIDO el 28 de abril de 2019 y ACEPTADO el 24 de enero de 2020

\section{INTRODUCCIÓN}

Existen dos momentos históricos importantes en los que fray Bartolomé de las Casas empleó la doctrina jurídica del derecho común para caracterizar a los indios como perso $\mathrm{n}$ as $\mathrm{m}$ is e rables. El primero es el acontecimiento de su famosa proclama pública a los feligreses de Chiapa, el 20 de marzo de 1545, y el segundo es la petición de jurisdicción de los obispos Bartolomé de las Casas, Antonio de Valdivieso y Francisco Marroquín a través de dos requerimientos dirigidos al presidente Alonso de Maldonado y a los oidores de la audiencia de los Confines, el 19 y el 22 de octubre de 1545. En esos tres documentos-la proclama y los requerimientos-, fray Bartolomé de las Casas, obispo de Chiapa, explicaba por primera vez la condición de las personae miserabiles asociada a los indios ${ }^{1}$. La persona miserabilis era una institución muy utilizada en la práctica jurídica del ius commune, pero hasta aquel entonces no había sido materia de debate entre los canonistas y juristas del derecho indiano. Se trataba de una caracterización jurídica nueva de los indios que argumentaba su protección y necesidad de justicia en el foro eclesiástico. Vista la naturaleza novísima de tal caracterización en aquel entonces, surge la inquietud acerca de cuáles pudieron ser las razones que condujeron al obispo Las Casas a considerar a los indios como personas miserables. Este trabajo tratará de distinguir los posibles presupuestos lascasianos para la consideración de los indios como personas miserables. Sin embargo, para responder a esta inquietud no bastará solamente con acudir a la proclama y a los requerimientos de Las Casas y a un análisis jurídico doctrinario de la institución

\footnotetext{
${ }^{1}$ Es la primera vez que Bartolomé de las Casas asociaba a los indios con las p e r s o $\mathrm{n}$ a s $\mathrm{m}$ i s e r a b l e s en sus escritos con base en el derecho canónico. Caroline Cunill señala que, en aquel pedido a la audiencia, "el dominico desarrollaba por primera vez esta doctrina". CUNILL, Caroline, El indio miserable: nacimiento de la teoría legal en la América colonial del siglo XVI, en Cuadernos Inter.c.a.mbio, 9 (2011), p. 229.
} 
europea de la persona miserabilis, sino que además necesitaremos situar el debate en el contexto histórico próximo al tiempo en que Las Casas desarrolló su teoría de los indios como $\mathrm{m}$ is e r a bles.

Las Casas, en su calidad de obispo de Chiapa, solicitó al presidente y a los oidores de la audiencia de los Confines que le reconocieran su jurisdicción en las causas de los indios, porque to dos los ind i os nat u rales eran personas miserables, y, bajo dicha consideración, en conformidad con el derecho canónico, el juez eclesiástico tenía jurisdicción sobre ellos. En el derecho común esto era posible aún cuando no hubiese negligencia del juez seglar, pero, en el caso de los indios era sobre todo importante por su estado de necesidad, de protección y defensa como personas o primidas, agraviadas y desampara$\mathrm{d}$ a s. La Corona trataba de remediar los agravios contra los indios por medio de ordenanzas para su protección. No obstante, las leyes corrían el riesgo de no ser ejecutadas en la práctica; de modo que la legislación por sí sola no constituía protección suficiente ni impedía el desamparo jurídico de los indios. A ojos de Las Casas, el mayor agravio que los indios padecían era estar sujetos al manejo de los encomenderos mientras su verdadera condición civil era la de vasallos libres del rey. Este fue el eje central de la lucha lascasiana, que perseguía nueva legislación del Consejo de Indias y del rey contra la perpetuidad de las encomiendas y en favor de la libertad de los indios. Las Casas pensaba que las encomiendas no solo vulneraban la libertad de los indios, sino que propiciaban los agravios en su contra e impedían su acercamiento a la fe católica. En 1542, Las Casas abogó nuevamente por los indios ante el real Consejo de Indias para que las Leyes Nuevas suprimiesen las encomiendas del todo, porque le parecía que ese era el remedio principal para las Indias; pero no logró completamente su cometido. Las Leyes Nuevas establecieron el cese inmediato de algunas encomiendas, pero pospusieron su erradicación definitiva. Hubo encomenderos obedientes que cumplieron la ley a satisfacción de la corona, sin embargo, también hubo muchos que se opusieron a las ordenanzas nuevas del rey. En aquel contexto, Las Casas fue elegido como obispo de Chiapa (1543). En marzo de 1544, fray Bartolomé recibía la ordenación episcopal, y al año de haber tomado posesión de su cargo describía el nuevo tratamiento a los indios como p e r s o $\mathrm{n}$ a s $\mathrm{m}$ is e rables. No nos sorprende, aunque si nos llama la atención, que Las Casas haya recurrido a una institución jurídica del derecho canónico para proteger a los indios, cuando por largo tiempo se había apoyado en las intervenciones directas de la Corona para alcanzar el buen gobierno de las Indias. Es posible, al menos eso creemos, que en medio de las circunstancias que le rodeaban -el incumplimiento de las leyes en favor de la libertad de los indios y el ejercicio de su nuevo encargo episcopal-, Las Casas hubiese pensado que era plenamente válido, a la luz del derecho común, acudir a la jurisdicción eclesiástica como un nuevo remedio para las Indias.

Los autores como Francisco Cuena y Mauricio Novoa, que han escrito sobre la condición jurídica de los indios como personas miserables, han propuesto conexiones entre el concepto y la casuística de la persona miserabilis en la tradición del ius commune y ciertas cualidades inherentes o aparentes en los indios, como las consideraciones de menores o de incapaces. Aunque en el contexto histórico que 
analizaremos tales consideraciones resultan algo forzadas ${ }^{2}$. La caracterización de Las Casas sobre los indios como personas miserables comprendía, esencialmente, su estado de vulnerabilidad y desamparo, similar, pero no igual al de las viudas, los huérfanos o pupilos. Pero, además, los indios vivían en un estado de opresión. He ahí la flexibilidad ínsita en el concepto de la persona miserabilis, cuyo carácter privilegiado y condescendiente subyacía tanto en el paradigma lascasiano como en la interpretación de la norma y en la práctica jurídica del ius commune. Precisamente, esa textura abierta de la ley imperial romana y el carácter flexible casuístico del ius commune, permitieron la consideración de los indios como un grupo más de personas miserables.

Este trabajo busca contribuir al estudio teórico del indio como pers o n a $\mathrm{m}$ is e r a b l e, incorporando elementos del pensamiento de fray Bartolomé de las Casas y del contexto que le animó a dar vida a esta categoría jurídica del ius commune en las Indias. Empezaremos dando una mirada a la institución de la persona miserabilis en el ius commune y al principio de la jurisdicción eclesiástica ex defectus iustitiae (I). Luego nos enfocaremos en la encomienda, cuyo impacto negativo sobre los indios se convertiría en un factor determinante para que Las Casas esté dispuesto a intervenir en su erradicación a través de las Leyes Nuevas (II). Finalmente, analizaremos los requerimientos de Las Casas y su caracterización de los indios como personas miserables (III).

\section{LA PERSONA MISERABILIS Y EL PRINCIPIO EX DEFECTUS IUSTITIAE}

\section{La persona miserabilis en el ius commune}

La condición jurídica de la persona miserabilis aparece descrita en la ley única

\footnotetext{
${ }^{2}$ Una primera consideración al respecto, es que, en los años previos a la proclama y a los requerimientos de Las Casas, acerca de la condición de personas miserables manifiesta en los indios, los teólogos como Francisco de Vitoria, habían mostrado interés en discutir temas de carácter antropológico que aludían a la condición racional de los indios, su libertad y capacidad de dominio, y a su entendimiento, incluso en temas vinculados a la fe. Estas proposiciones precedieron el debate conocido como la controversia de Valladolid, entre Bartolomé de las Casas y Juan Ginés de Sepúlveda (1550-1551), en el que Las Casas afirmaba su tesis sobre la racionalidad de los indios y su grado de igualdad con los españoles. Décadas más tarde, cuando la Corona se pronunció sobre los indios como p e $\mathrm{r} s$ o $\mathrm{n}$ a $\mathrm{s} \mathrm{m}$ i s e $\mathrm{r}$ a b l e s, tomaba como referencia su estado débil y oprimido. De tal manera, vemos que en aquel entonces no hubo un planteamiento inequívoco sobre la condición de los indios como personas miserables por alguna presunción o grado de incapacidad o minoridad. En segundo lugar, cabe la consideración de ciertas características propias del derecho indiano, como su capacidad de respuesta directa ante problemas concretos, y su flexibilidad para adecuar el derecho a los datos de la realidad, pues fue gracias a esa disposición para remediar los problemas de los indios, que eventualmente se adoptaría la institución de la persona miserabilis en las Indias. Francisco de Vitoria en su relección De indis recenter inventis relectio prior, cuestionaba si era necesario el uso de razón para tener capacidad de dominio, y luego de analizar los supuestos de irracionalidad y de niñez concluyó que los indios tenían dominio sobre sus cosas y eran verdaderos señores antes de la llegada de los españoles. ViTORIA, Francisco de, De los indios, relección primera, en URDANOZ, Teófilo (ed.), Obras de Francisco de Vitoria, Relecciones teológicas (Madrid, La Editorial Católica, 1960), p. 666.
} 
Imp. Constantinus A. ad Andronicum del año 334³. La ley imperial de Constantino comprendía entre las personas miserables a los menores no sujetos a patria potestad, las viudas, los enfermos y los débiles o inválidos, y les concedía beneficios procesales en sus causas o procesos ${ }^{4}$. La definición de la persona miserable, desde su instalación en Roma, se abrió a la posibilidad de una clasificación más extensa, que acogiese a diferentes grupos de personas susceptibles de adquirir la condición de miserables, o asociados al carácter de dicha condición. A la luz de este principio, surgió una interpretación jurídica abierta, que amplió el concepto jurídico de la persona miserabilis para abarcar a nuevos grupos de personas. La doctrina y la casuística de ius commune la doctrina incorporó nuevas clases de personas miserables, como señalaba el jurista castellano Gabriel Álvarez de Velasco: pobres, ancianos, peregrinos, rústicos, menores de edad, cautivos, siervos, clérigos, encarcelados, meretrices, los nuevos en la fe, vírgenes, célibes, pródigos ${ }^{5}$. Incluso se aceptaron personas jurídicas con personalidad moral, como las universidades ${ }^{6}$. La persona miserabilis como institución gozaba de un estatus protegido a través de ciertos privilegios procesales, que adquirieron el carácter de principios, y que podríamos resumir en cinco: jurisdicción, excepcionalidad, temporalidad, territorialidad y elección preferente del juez. i) jurisdicción: solo el juez tenía el arbitrio para decidir si una persona tenía la condición de miserabilis; ii) excepcionalidad: debía determinarse la existencia de motivos razonables que configurasen la posición de desventaja en el proceso (frente a otro poderoso); iii) temporalidad: solo era aplicable en el ámbito jurídico por tratarse de una condición personal que otorgaba privilegios mientras durase el proceso; iv) territorialidad: las personas miserables no podían ser llevadas como reos a tribunales fuera de su provincia, ni estaban obligadas a trasladarse fuera de sus provincias para defenderse y litigar; y, v) elección preferente del juez: podían escoger los tribunales que más les conviniesen para ver sus causas, o pedir otros tribunales incluso en primera instancia. Podían acudir a la curia o al tribunal del príncipe.

${ }^{3}$ Lex (ley) Si contra - quando imperator inter pupillos vel viduas vel miserabilis personas cognoscat et ne exhibeantur = C. 3, 14, 1: "Si contra pupilos viduas vel diutino morbo fatigatos et debiles impetratum fuerit lenitatis nostrae iudicium, memorati a nullo nostrorum iudicum compellantur comitatui nostro sui copiam facere. Quin immo intra provinciam, in qua litigator et testes vel instrumenta sunt, experiantur iurgandi fortunam atque omni cautela servetur, en terminos provinciarum suarum cogantur excedere. 1. Quod si pupilli vel viduae aliique fortunae iniuria miserabiles iudicium nostrae serenitatis oraverint, praesertim cum alicuius potentiam perhorrescunt, cogantur eorum adversarii examini nostro sui copiam facere [a. 334]". p. 108.

${ }^{4}$ Cuena, Francisco, Utilización pragmática del derecho romano en dos memoriales indianos del siglo XVII sobre el protector de indios, en REHJ., 20 (1998), Ibíd., pp. 108-109.

${ }^{5}$ Paulino Castañeda emplea una variedad de definiciones y clases de personas miserables. Citando a Álvarez de Velasco, enumera esta lista: "pregrinis, rusticis, pauperibus, minoribus, captivis, Ecclesia, Ecclesiasticis, personis, iis servientibus, civitate, meretrice, scholaribus, publice poenitentibus, expositis, senibus, coecis, carceratis, noviter ad fidem conversis, cruce signatis, virgine, celibe, nupta inutilem maritum habente, milite, prodigo [...]". CASTAÑEDA, Paulino, La condición miserable del indio y sus privilegios, en Anuario de Estudios Americanos, 28 (1971), p. 254.

${ }^{6}$ Ibíd., pp. 254; 258. 


\section{La jurisdicción eclesiástica y el principio ex defectus iustitiae}

La naturaleza del derecho canónico clásico se caracterizó por su amplia cobertura, que no se limitaba a materias puramente eclesiásticas, sino también seculares. Su estructura permitía fluidez en temas de competencia jurisdiccional. Algunas materias del derecho canónico ofrecían contenidos mixtos, de modo que bien podían ser vistos en el foro secular como en el foro eclesiástico ${ }^{7}$. Un ejemplo claro de contenidos mixtos es la institución de la persona miserabilis, cuya protección era competencia de los jueces ordinarios y de los jueces eclesiásticos, bajo la materia de la jurisdicción eclesiástica ex defectus iustitiae. Este principio establecía que el derecho canónico podía intervenir en materias seculares, para corregir la falta de justicia en el foro secular ${ }^{8}$. Con esto se postulaba un sistema flexible en la aplicación del privilegio jurisdiccional a favor de las personas miserables. Sin embargo, la doctrina de los juristas y de los canonistas mostraba discrepancias respecto a cuál de las jurisdicciones debía tener preferencia. R.H.

Helmholz explica que no existió algo parecido a un título separado y específico sobre la jurisdicción eclesiástica de las personae miserabiles en los textos del derecho canónico 9 . En las decretales del papa Inocencio III, "De foro competente", acerca de la jurisdicción eclesiástica en materias seculares, los canonistas interpretaban que de no obtenerse la justicia adecuada en el foro secular, correspondía a los jueces eclesiásticos aplicar su jurisdicción ${ }^{10}$. Helmholz señala que la jurisdicción ex defectus iustitiae era la excepción que más destacaba en los casos inadecuados para el fuero secular. Pero, podía considerarse también un defecto la situación en la que el juez secular denegase expresamente la justicia o cuando su denegación de justicia fuese notoria ${ }^{11}$. Paulino Castañeda explica, de acuerdo a los tratadistas, que había una correspondencia entre el tipo de jurisdicción y ciertas características de la miserabilidad: "si son oprimidos, pueden traer a sus opresores al juez eclesiástico; si no son subyugados deben primero recurrir al juez laico; y los que no son miserables actu nec habitu, no pueden recurrir al fuero de la Iglesia a no ser que sean de ese fuero" ${ }^{\prime 2}$.

Hubo juristas contemporáneos a Las Casas, como el licenciado Gregorio López, que contemplaron la intervención de la jurisdicción eclesiástica en las causas de los indios, por razones asociadas a su lejanía del rey y por ser nuevos en la fe.

${ }^{7}$ En ocasiones la jurisdicción no dependía de la materia sino del tribunal que hubiese actuado primero. Es decir, las partes tenían la facultad de elegir ya sea una corte eclesiástica o secular para presentar sus quejas. Helmholz, R. H., The Spirit of Classical Canon Law (Athens, Georgia; The University of Georgia Press, 1996), p. 117.

${ }^{8}$ Ibíd., p. 118.

${ }^{9}$ Helmholz señala que ni siquiera en las decretales se hallaba certeza acerca del modo en que éste tipo de jurisdicción eclesiástica se extendería a los miserables. Pero, aunque no se disponía de provisiones exactas para asistir a las personas miserables en la práctica, sí existía un interés común, tanto al fuero eclesiástico como al fuero secular, de conceder protección especial a los huérfanos y a las viudas, y defensa a los débiles [C.23 q. 5 c. 23]. Helmholz, R. H., cit. (n. 7), p. 125.

${ }^{10}$ Ibíd., p. $118 \mathrm{s.}$

${ }^{11}$ Ibíd., pp. 132-133.

${ }^{12}$ Castañeda, Paulino, cit. (n. 5), p. 261. 


\section{LA JUSTICIA Y LAS CONTROVERTIDAS NUEVAS ORdENANZAS DE INDIAS}

\section{La perpetuidad de la encomienda contraria a la libertad de los indios}

Demostrar formalmente la protección del monarca hacia los naturales del Nuevo Mundo a través de la legislación, era propio de la cultura jurisdiccional hispánica ${ }^{13}$. El monarca cumplía el papel de protector y defensor del orden social en los nuevos reinos incorporados al dominio de la Corona castellana. Además, como juez supremo, el rey debía garantizar los derechos de sus nuevos súbditos, entre ellos su libertad ${ }^{14}$. Las Casas consideraba que los indios poseían una libertad idéntica al resto de los seres humanos, y que el rey no tenía una potestad que le permitiese conculcar la libertad de otro ${ }^{15}$, razón por la cual estaba impedido de tratar a los indios como esclavos.

A inicios del siglo XVI, por disposición de la reina Isabel, se aprobaron oficialmente los repartimientos de indios -sinónimo de encomiendas-, ${ }^{16}$ y el pago de una remuneración por los trabajos que los indios realizasen para los encomenderos ${ }^{17}$. La composición de la encomienda indiana, a modo de repartimiento de mano de obra $^{18}$, importó la sujeción de los indios a los encomenderos y su sometimiento

${ }^{13}$ Temprano en la conquista, aparecen provisiones de los reyes de Castilla favoreciendo el buen trato de los indios. Tomamos algunas líneas de una provisión de doña Juana y el rey Carlos (1518), sobre el buen tratamiento de los indios encomendados, que incluía el miramiento e instrucción de la doctrina católica. Esta provisión no fue la primera, ni sería la última de una serie de intervenciones de la Corona para tratar de contener los agravios contra los indios: "[...] no se ha guardado las dichas ordenanzas y a havido en ello much a negligencia y descuydo [...] por lo que nuestra intención es que de agora en adelante se remedie para que los dichos mujeres e indios sean bien tratados como vasallos nuestros e dotrinados e ynstruydos en las cosas de nuestra fe católica e se salven [...]". Archivo General de Indias, Ordenanzas para los indios encomendados (1518, diciembre, 19, Zaragoza, sign. Indiferente, 419, L. 7, f. 815v-825v, 1r [acceso en línea en: http://pares.mcu.es].

${ }^{14}$ Del monarca se esperaban las más altas virtudes, principalmente, la virtud de la justicia, porque en él recaía el poder de la jurisdicción y consigo el deber de decir el derecho e impartir justicia (dar a cada uno lo suyo). DE LA PUENTE, José, Encomienda y encomenderos en el Perú (Sevilla, Dialpa, 1992), p. 51.

${ }^{15}$ Las Casas escribió sobre la servidumbre y la libertad inherente a los hombres: “[...] todos los hombres, todas las tierras y todas las otras cosas, por derecho natural y de gentes, fueron libres $y$ alodiales, o sea francas y no sujetas a servidumbre". Citando a Santo Tomás, decía que la naturaleza racional del hombre no se orienta a otro como fin, por lo tanto no existe servidumbre natural, sino accidental. DE LAS CASAS, Bartolomé, De regia potestate o derecho de autodeterminación (Madrid, Consejo Superior de Investigaciones Científicas, 1969), pp. 16 ss.

${ }^{16}$ Esta institución se ajusta a la encomienda medieval temprana o "repartimiento en la España de la reconquista", por la cual el encomendero percibía el usufructo de las tierras que se ponían bajo su protección. DE LA PuENTE, José, cit. (n. 14), p. 14.

${ }^{17} \mathrm{La}$ encomienda se adoptó legalmente en las Indias en 1503, por medio de una real cédula expedida por la reina Isabel. Dicha disposición regularizaba la práctica de la encomienda, que desde el establecimiento de Colón hasta aquel entonces no exigía el pago de un salario al indio. Ibíd., p. 15.

${ }^{18}$ Una vez destituido Cristóbal Colón por la reina Isabel a causa del negocio de esclavos que pretendió crear con los indios de las Antillas, el nuevo gobernador Nicolás de Ovando, comendador de la orden de Calatrava, organizó la encomienda de indios a modo de repartimiento de mano de obra, pero bajo claras instrucciones de la reina Isabel de velar por su buen tratamiento. 
forzoso a trabajar en la mita -trabajo obligatorio de los hombres en las minas-a cambio de un salario, lo cual les correspondía por tratarse de ho mbres libres ${ }^{19}$. La reina Isabel insistió en que los encomenderos no debían ver a los indios como esclavos, ni debían tratarlos como tales. Sin embargo, a pesar del interés de la Corona en proteger a los indios y reconocerles su condición de vasallos libres en la ley, la realidad del maltrato que llegaba a oídos del monarca demostraba que aquella libertad estaba reservada al papel y a la tinta. Tan pronto como las encomiendas se instalaron en América hispánica, se notó que el sistema de repartimientos se acomodaba mejor a los intereses de los españoles que a los intereses de los indios, lo que dio lugar a quejas y disputas en los años posteriores a su advenimiento.

La mención pública más conocida sobre el maltrato hacia los indios, que hacía alusión directa a la institución misma de la encomienda ${ }^{20}$, ocurrió el cuarto domingo de Adviento de 1511 en la Isla de La Española, cuando en el púlpito de la iglesia, y ante los colonos de la isla, fray Antonio de Montesinos expuso los abusos que se cometían contra los indios, y exhortó a los encomenderos a cambiar de comportamiento ${ }^{21}$. Aquel sermón ${ }^{22}$, que descargó la conciencia de los frailes dominicos que habitaban en la isla, sólo consiguió desatar la ira de los encomenderos, avivando su deseo de mantener a los indios sujetos a sus prerrogativas. Si algo esperaban los encomenderos como resultado de aquel discurso, era que el monarca pusiese orden entre los frailes dominicos por haberles cuestionado su autoridad y, por ende, la autoridad del mismísimo rey ${ }^{23}$. Aquel debate marcó un precedente sobre el señorío de los encomenderos como un privilegio personal del rey que no podía soslayarse tan fácilmente.

Los encomenderos obtenían el control de la encomienda por merced de la Corona. La encomienda les proporcionaba fuerza de trabajo indígena, tierras y

Dumont, Jean, El amanecer de los derechos del hombre: La controversia de Valladolid (trad. cast., María José Antón; Madrid, Ediciones Encuentro, 2009), pp. 45-48.

${ }^{19}$ DE LA Puente, José, cit. (n. 14), p. 15.

${ }^{20}$ Ibíd., p. 16 s.

${ }^{21}$ El fraile dominico, Montesinos, criticó la servidumbre de los indios y los excesivos abusos que padecían en las minas de oro, además del poco cuidado que los españoles mostraban por sus vidas. Protestó también sobre el maltrato espiritual a los indios, bajo la cuestionada autoridad de los españoles, que les impedía conocer a Dios; tampoco era posible para los españoles mismos practicar, de esa manera, el amor cristiano.

22 "[...] Decid, ¿con qué derecho y con qué justicia tenéis en tan cruel y horrible servidumbre apuestos indios? ¿Con qué autoridad habéis hecho tan detestables guerras a estas gentes que estaban en sus tierras mansas y pacificas; donde tan infinitas dellas, con muertes y estragos nunca oídos, habéis consumido? ¿Cómo los tenéis tan opresos y fatigados, sin dalles de comer ni curallos en sus enfermedades, que de los excesivos trabajos que les dais incurren y se os mueren, y por mejor decir, los matáis, por sacar y adquirir oro cada día? [...]". DE LAS CASAS, Fray Bartolomé, Historia de las Indias (1552, 2a ed., Fondo de Cultura Económica, México, 1986), p. 441.

${ }^{23}$ Aquel sermón encendió la ira de los encomenderos, según el relato de Bartolomé de las Casas, en su Historia de Indias. En aquellas palabras, los encomenderos notaron el agravio directo a la autoridad del rey, de quien habían recibido las encomiendas. Las Casas escuchó aquel sermón de fray Anton de Montesinos, como encomendero que era en esas tierras, pocos años antes de regresar a España para ingresar a la orden de Santo Domingo. Sus experiencias en La Española le formaron una conciencia propia de la realidad de aquellas gentes entre quienes vivía, desarrollando un especial interés en defender la condición humana de los indios. 
tributos con derechos de sucesión por varias vidas; privilegios que les rindieron estatus social y poder político que desafiaba incluso el poder del monarca ${ }^{24}$. En cambio, sobre los indios recayeron la carga del trabajo forzoso en las minas, la servidumbre personal y la carga tributaria impuesta sobre su salario. Ni siquiera la evangelización pudo matizar la percepción negativa que acompañaba a la encomienda, porque los trabajos que los encomenderos imponían sobre los indios, sea en la minas o en los servicios personales, les impedían asistir a explicación de la doctrina. Las Casas escribió sobre los excesivos trabajos que los indios realizaban, y el poco tiempo del que disponían para su conversión, "[...] que Vuestra alteza remedie con efeto las tyranias y opresiones fuerças y agravios que padecen mis ovejas los yndios naturales de todo aquel obispado [...] que los cuerpos perecen en las anymas porque como los tienen los españoles siempre en las dichas sus tyranias ocupados no pueden los rreligiosos a verlos para les predicar la ley de Dios y convertirlos y para esto es necesario que Vuestra Alteza les de la libertad que su magestad manda por sus nuevas ordenanças [...]"25. Para fray Bartolomé era importante que los indios fuesen liberados de las encomiendas, como el rey había ordenado en las Leyes Nuevas, pues consideraba que iba en perjuicio de su conversión que estuviesen sujetos a los encomenderos y dedicasen tanto tiempo a los servicios personales.

El sistema de la encomienda y los servicios personales eran factores limitantes para el acceso a la doctrina. Parecido sentir tuvo el religioso, fray Pedro de Mura o Pedro de Gante, un importante fraile franciscano de origen belga que vivió muchos años en Nueva España. Fray Pedro le escribió una carta al rey Carlos para explicar el poco tiempo que les quedaba a los indios para acercarse a la $\mathrm{fe}^{26}$. También exponía los manejos inadecuados que los encomenderos hacían de los servicios personales, y se quejaba de los agravios contra los indios por su causa. Le pedía al rey que nadie pudiese servirse de los indios: "[...] Vuestra magestad haga cumplir las cedulas que a mandado enviar cerca de los servicios personales, porque una de las principales cosas que a esta gente destruye es ello [...] porque la horden que en esto de los servicios se tiene, es que cada dia meten en casa del encomendero

\footnotetext{
${ }^{24}$ Las encomiendas se entregaban en honor al mérito de las personas que hubiesen servido a la Corona, o a quienes tuviesen cédulas de merced de su majestad. Incluso hubo encomenderos que residían en España y contrataban mayordomos para velar por sus encomiendas. Con el tiempo, tuvieron encomiendas no solamente los beneméritos por su servicio a la Corona, sino también personas sin mérito alguno, que accedían a ellas a través de matrimonios por conveniencia. $\mathrm{DE}$ la Puente, José, cit. (n. 14), pp. 48-52; 76-78.

${ }^{25}$ Las nuevas ordenanças hacen referencia a las Leyes Nuevas, que se promulgaron en 1542 y se empezaron a ejecutar desde 1543. Archivo General de Indias, Bartolomé de las Casas: vulneración dignidad episcopal (1545, sign. Patronato, 252, R. 10), f. 4. Acceso en línea en http://pares.mcu.es

26 "[...] porque aun para deber de buscar sus mantenimientos les falta tiempo, y ansi se mueren de hambre y se despueblan por el demasiado trabajo, [...] cierto yo bien creo que la intencion de Vuestra magestad es que se salven y que conozcan a dios, pues para esto necesario es que se les procure el sosiego para que con mediano trabajo en el tributar del todo se den a oyr la doctrina [...] por el remedio de ellos pues para se poder salvar esta gente an menester mucho ser sobre llevados para que vaquen algun tanto a las cosas de la fee, pues no fueron descubiertos sino para buscalles su salvación, lo qual de la manera que agora van ello es imposible [...]". Archivo Histórico Nacional de España, Carta de Pedro de Gante sobre el servicio personal de indios, (1552, febrero, 15, San Francisco de México, Diversos-colecciones, 23, N. 59), f. 1r [acceso en línea en: http://pares.mcu.es].
} 
servicio [...] y son tan mal tratados de la gente de los esclavos, negros e criados de los tales que en lugar de dalles de comer los mal tratan de palabra y de obra malamente [...] porque sepa Vuestra magestad que los yndios de servicio son esclavos de los negros $y$ assi los mandan e gastigan como el propio amo [...]"27. Pedro de Gante lamentaba que los indios viviesen oprimidos y mortificados por causa de los encomenderos y del tributo que les era exigido aunque fuesen pobres, y porque se les imponía servicios personales aún en contra de su voluntad y a cambio de una retribución tan pobre que no les alcanzaba para vivir ${ }^{28}$.

El incumplimiento de las Leyes Nuevas que ordenaban la libertad de los indios, generaba tensión y conflictos entre los encomenderos y los religiosos, pues lo que para unos constituía una merced -que los indios trabajen para generarles tributo y servirles-, para los otros era un impedimento en la instrucción de la fe. A Pedro de Gante le parecía que los indios vivían antes para servir a los encomenderos y para el tributo que para conocer a $\operatorname{Dios}^{29}$. La encomienda perpetuaba la pobreza de los indios que, una vez dentro del sistema, trabajaban principalmente para el sostenimiento de los encomenderos, y lo que recibían en pago apenas les servía para sostenerse ellos mismos y a sus familias ${ }^{30}$.

\section{Los indios en la cabeza del rey}

La perpetuidad de la encomienda era un asunto problemático para el tutelaje

${ }^{27}$ Ibíd.

28 "[...] les tienen mandado que de cada pueblo de las dichas diez leguas a la redonda trahigan como les cabe cada yndio una carga de leña a Mexico, y lo que en ello ay y el agravio que reciben es que esta dos dias en cortilla y traella a Mexico y otro en bolver a su casa, o otros dos y ha venido cargado y muerto y ha comido la miseria que tenia en su casa y despues danle por la carga medio rreal aviendo el comido uno y su trabajo en blanco, o crueldad grande [...] Vuestra magestad como cristianisimo lo remedie evitando en todo el servicio personal y proveyendo que no se alquilen contra su voluntad e que tributen de los que en sus pueblos tienen, pues otros remedio ninguno [...] Los quales siendo en tiempo pasado señores e mandado en toda la tierra, son agora esclavos, y aun mas que esclavos, y como estos sirban a toda la ciudad asi a principales como a menores, y en especial en casa destos que en nombre de Vuestra magestad goviernan y su muger le busca la comida para ella y para el y sus hijos y para tributar, y lo que ha de hazer el indio haze ella y se va la yndia a cargar para traer la leña y yerva, porque esta su marido sirviendo personalmente y no puede, pues mire Vuestra magestad si sera sufrible este trabajo, por cierto que quanto a la sustentación y descanso mejor los pasan los perros que los yndios, porque a los perros danles de comer, mas a estos sirbense dellos y no se lo dan [...]”. Archivo Histórico Nacional de España, Carta de Pedro, cit. (n. 26), f. 1v-2r.

${ }^{29}$ Luego de promulgadas las Leyes Nuevas en la Nueva España, fray Pedro de Gante le hacía ver al rey que los servicios personales y el pago del tributo seguían acabando con los indios: "[...] mas de que se de cierto que si esto no se quita ellos se acabaran presto, pues se disminuyen, como el pan que se va comiendo cada día, [...] nunca en parte del mundo se vio tributar los hombres delo que no tienen como estos y assi como ayan de buscar el tributo fuera nunca sosiegan, [...]". Archivo Histórico Nacional de España, Carta de Pedro, cit. (n. 26), f. 1r.

${ }^{30}$ Pedro de Gante le pedía al rey por los indios de Xalisco que eran muy pobres: "Que la tierra de Xalisco que agora se convierte a nuestro señor e al servicio de vuestra magestad deben ser reservados de tributar y de servir y la causa es porque es gente pobre e que no sabe quecosa es servir [...] y no saben que cosa es tributar ny servir y an menester estar algum tiempo en libertad para que se les de a entender la doctrina [...]". Archivo Histórico Nacional de España, Carta de Pedro, cit. (n. 26), f. $2 \mathrm{v}$. 
de los indios a cargo de la Corona castellana, porque le atribuía poder a la clase española -conquistadores, encomenderos, mayordomos y administradores- que controlaba los repartimientos en el Nuevo Mundo ${ }^{31}$. La forma del reparto de indios variaba. Podía tratarse de concesiones hechas por los conquistadores en calidad de depósito con indios sujetos al servicio personal; concesiones en depósito con indios tasados para el tributo, como hizo el conquistador Francisco Pizarro ${ }^{32}$, o repartimientos cedidos por mercedes del rey. Cualquiera que fuese el modo de la encomienda, tenía siempre la misma finalidad: el beneficio económico para la Corona y para los encomenderos. Sin embargo, la Corona buscaba transformarlas en cesiones únicamente de tributos ${ }^{33}$, para luego retirarlas del todo a través de las Leyes Nuevas (1542). También, hubo grupos de colonos españoles que habían llegado tarde al reparto de encomiendas, y otros defensores de los indios como Las Casas, que buscaban cambios en el gobierno de sus provincias ${ }^{34}$.

Más allá de la incompatibilidad entre la sujeción de los indios a los encomenderos y su estatus de vasallos libres -que tanto le preocupaba a Las Casas-, lo que hacía la situación intolerable era que los encomenderos se sirviesen de ellos como si fuesen esclavos. Esto era un desacato a las leyes y un modo de arrebatarles la dignidad humana. Claramente, desde la óptica flexible y el carácter protector que caracterizaron la creación de las leyes para las Indias, la perpetuidad de la encomienda no encontraba una razón legítima que la justificase, de manera que, gradualmente, la idea de anteponer el derecho a la libertad de los indios por encima de los intereses de los encomenderos, empezaba a tomar más importancia para la Corona.

Bartolomé de Las Casas esgrimía el principio de la n o e n a j e n a c i ó n sobre los vasallos libres como uno de los argumentos para colocar a los indios en la cabeza del rey ${ }^{35}$. Utilizó el Digesto y la filosofía tomista para justificar la libertad inherente a los seres de naturaleza racional, y negar la esclavitud. Ni siquiera el vasallaje, como forma de servidumbre, permitía que se pierda la libertad con el juramento de fidelidad ${ }^{36}$. Las Casas reclamaba la terminación de la encomienda, porque los indios eran libres bajo la ley y les correspondía estar sujetos directamente al rey. Además, porque sólo de ese modo gozarían de un tratamiento libre de agravios ${ }^{37}$.

${ }^{31}$ DE LA PUenTe, José, cit. (n. 14), p. 16.

${ }^{32}$ Ibíd., p. 20 s.

${ }^{33}$ De la Puente explica, que el núcleo de la encomienda es el tributo, cedido por el monarca a favor de quienes le ayudaron a incorporar los nuevos territorios descubiertos. Ibíd., pp. 17-20.

${ }^{34}$ Ibíd., p. 22.

35 "Entre todos los perjuicios que pudieron de hecho inferir los reyes a sus pueblos parece más grave, incluso el de máxima gravedad, enajenar de la Corona y someter a la jurisdicción de otro señor particular a ciudadanos o súbditos por vía de venta, donación, delegación, concesión o privilegio", LAS CASAS, Bartolomé, De regia potestate, cit. (n. 15), p. 8.

${ }^{36}$ Ibíd., pp. 16-18. "Y en esto se diferencia el esclavo del hombre libre: Pues toda prohibición, sea temporal o perpetua, se opone a la libertad". Ibíd., p. 19.

${ }^{37}$ En sus pedidos reiterados al rey y al Consejo de Indias, Las Casas reclamaba que los indios fuesen liberados. José de la Puente recoge algunos argumentos de Las Casas propuestos por Silvio Zavala: "[...] éstas [encomiendas], por demostración de la experiencia, eran nocivas; los indios, como seres libres, merecian gobierno libre, no tutelado; su gobernación no habia de darse a los 


\section{Bartolomé de las Casas y las Leyes Nuevas}

La percepción de los motivos que encabezaron la conquista española -el recaudo de oro y plata, y la expansión de la fe católica entre los naturales-, polarizaron la política indiana y la justicia. Lewis Hanke bien señala en su obra titulada Spanish Struggle for Justice, que en medio de la conquista española surgieron dos interpretaciones conflictivas sobre la justicia: una visión de la justicia que se fundaba en la esclavitud virtual de los indios como medio para desarrollar los recursos del Nuevo Mundo en beneficio de la Corona; y la otra que sostenía la prioridad de la persona del indio, su conservación y su conversión a la fe católica. La intensa lucha política para que una de las dos visiones prevaleciese sobre la otra era un asunto entre los conquistadores y los clérigos ${ }^{38}$, pero, conseguir un gobierno justo con los indios era, fundamentalmente, materia del rey.

En 1540 Las Casas viajó a España para pedir una reforma trascendente en el gobierno de las Indias ${ }^{39}$. Dos años más tarde, el emperador Carlos V convocó a la Congregación General sobre la Reformación y Remedios de las Indias (1542). En esa ocasión, Bartolomé de las Casas expuso las razones y remedios que, a su juicio, debían implementarse para el mejor gobierno de las Indias. El parecer del fraile dominico, que consta en un documento oficial, pero que es de autoría de Las Casas $^{40}$, contiene una lista de principios (6), y una lista de remedios universales (16) y particulares (18). En el quinto principio, Las Casas planteaba la obediencia y sujeción de los indios al emperador: "[...] consiste, después de en bivir los yndios el ser traydas aquellas gentes y reynos asi delas descubiertas como todas las que estan por descubrir a la obediencia y subjeción Imperial y señorio de su Majestad y de sus subcesores $[\ldots]^{41}$. En el octavo remedio particular, que Las Casas estimaba como "el fin de todos los remedios de las yndias", instaba al rey a retirar a los indios de las encomiendas e incorporarlos directamente a la Corona: "[...] que su Magestad es obligado de precepto divino a encorporar en su real corona todos los yndios de todas las yndias como vasallos libres que son y quitallos de las encomiendas de los cristianos y no dallos pocos ni muchos por vasallos ni con otro titulo alguno a ningun cristiano de ninguna calidad que sea [...]"42. Para este remedio particular elaboró veinte fundamentos que ponían énfasis en las injusticias contra los indios y en la obligación de los reyes de Castilla de resolver los inconvenientes que existían para su

hombres injustos; el vasallo no debe soportar muchos amos; es preferible la administración regalista a la señorial; hay antecedentes legales a favor de la libertad de los indios y contra el régimen de las encomiendas; Dios, España y la Corona, y aun los propios españoles pierden si se conserva este nocivo sistema”. Véase DE LA PUENTE, José, cit. (n. 14), p. 23.

${ }^{38}$ Hanke, Lewis, Spanish Struggle for Justice (Boston, Little, Brown and Company, 1965), p. 7.

${ }^{39}$ Pérez, Isacio, Autenticidad, sentido histórico y valor capital de este documento, es el comentario a las Conclusiones sumarias sobre el remedio de las Indias de Fray Bartolomé de las Casas (1542), p. 6.

${ }^{40} \mathrm{El}$ resumen fue hecho por el mismo fray Bartolomé de las Casas, según señala el padre Isacio Pérez Fernández. Ibíd., pp. 3 ss.

${ }^{41}$ DE LAS CASAS, Bartolomé, Conclusiones sumarias sobre el remedio de las Indias (1542, Madrid, ed. facs., 1992), f. 1r.

${ }^{42}$ Ibíd., f. 4v. 
conversión; un compromiso que la Corona había adquirido por elección de la sede apostólica ${ }^{43}$. Las Casas se empeñaba en explicar que la sujeción al rey era la norma general para sus vasallos libres y que carecía de validez cualquier acto que pretendiese trasladar la sujeción a otro que no fuese el rey sin el consentimiento de los indios ${ }^{44}$. Otra razón jurídica utilizada por Las Casas para retirar la encomienda era el mal uso del privilegio concedido por el rey a los encomenderos, a quienes acusaba de haber causado destrucción y muerte entre los indios ${ }^{45}$. Acerca de las eventuales oposiciones contra la libertad de los indios y la prohibición de nuevos repartimientos, Las Casas argumentaba que a pesar de los probables inconvenientes que la ley pudiese suscitar entre sus opositores, era imposible entregar indios a manos de quienes les causaban daño, pues era ilícito, sin duda alguna, hacer un mal porque de él se siguiese, aparentemente, un bien ${ }^{46}$. Por lo visto, Las Casas creía que todos los males cesarían cuando la encomienda cayese y los indios estuviesen todos en la cabeza del rey. Su postura influyó en la creación de las Nuevas Ordenanzas de Indias, conocidas como las Leyes Nuevas (1542), que en el capítulo XXX prohibían la encomienda hereditaria; aunque, como tal, causó tanta conmoción en algunos territorios, que tuvo que ser matizada por la Corona. La retirada gradual de la encomienda nunca fue la propuesta de Las Casas, quien más bien buscaba la liberación total e inmediata de los indios de sus encomenderos. Sin embargo, en su segundo requerimiento dirigido al presidente y a los oidores de la audiencia de los Confines (1545), Las Casas aceptaba obedientemente las ordenanzas del rey, pese a sus alcances limitados ${ }^{47}$.

\section{Algunas repercusiones causadas por las Leyes Nuevas}

La ejecución de las Leyes Nuevas encontró oposición en casi todos los territo-

${ }^{43}$ Ibíd., fs. 4v-6r.

44 "La 9a. porque todas aquellas gentes y pueblos de las yndias son libres y recognoscientes superiores ly el señorio de los reyes de castilla no se les da sino para que sea dulce y benigno y para su provecho y para mayor y mas segura libertad y en favor de la fe por manera que por subjetarse a su majestad no hazen deterior ni menos libre su estado, y por consiguiente sin su voluntad y consentimiento no puede su majestad sacallos de su real corona y dallos a quien le plugiese porque son libres en el mayor grado de libertad que ymaginar se puede". Ibíd., fs. 4v-5r.

45 "La 10" porque la ley divina y natural y las leyes humanas lo dictan que quien usa mal del previllegio concedido le sea quitado y el previllegio luego que comiença a ser nocivo es ypso jure nullo - los cristianos an destruydo y cada dia destruyen y matan los yndios que les dieron para que se aprobechasen y por tanto son yndignos y como estas encomiendas sean en total destrucción dellos ypso jure son nullas y su magestad no puede hazellas validas [...]". Ibíd., fs. 5r-5v.

46 "[...] aunque subcediesen cuantos ynconvenientes pudiesen seguirse no por eso se les avian de dar pues los matan quienes sunt facienda mala ut eveniant bona-quanto mas que todos cesan con el $8^{\circ}$ remedio". Ibíd., f. 6.

47 “[...] esta claro lo que pido que no es quitar los yndios a los particulares porque el Rey no lo manda sino a los officiales para dar de comer a quien no lo tiene y si esto oviera entendido el pueblo no oviera avido tanto daño ni pensaran los españoles que las leyes de su magestad les eran dañosas y que les quitavan la sustentación”. Archivo Histórico Nacional de España, Requerimiento obispo de Chiapa sobre limites de su autoridad, (1545, octubre 22, Gracias a Dios, sign. DiversosColecciones, 23, N. 1), f. 4r [acceso en línea: http://pares.mcu.es]. 
rios indianos ${ }^{48}$. En el Perú resultó en un fracasó político para la Corona, porque los encomenderos se alzaron contra el virrey y la encomienda no solamente continuó, sino que se hicieron nuevos repartimientos ${ }^{49}$. Un memorial de lo ocurrido luego de la llegada de Blasco Núñez Vela como primer virrey del Perú, describía el trastorno que las Leyes Nuevas causaron entre los encomenderos y los pobladores ${ }^{50}$. En la Nueva España, el virrey Antonio de Mendoza ya había proveído algunas licencias sobre los servicios personales en los años anteriores a la promulgación de las nuevas ordenanzas del rey, como permitir a los indios que "se carguen de su voluntad”. Luego de recibir las Leyes Nuevas, el virrey Mendoza envió al rey una relación sobre los servicios personales. En dicho documento negaba que los tamemes $^{51}$ fuesen tratados como bestias de carga. Pero, por otro lado, justificaba sus servicios de carga en vista del número reducido de mulas disponibles para cargar en las minas, donde su fuerza de trabajo era útil. Asimismo, explicaba que los indios eran necesarios en el comercio y en el transporte de madera y de artillería, por las inconveniencias de la geografía del territorio para el transporte en carretas o en bestias. Por estas razones, le parecía precipitado retirar los servicios personales ${ }^{52}$, y mostró su renuencia a tasar nuevamente a los indios ${ }^{53}$. Al mismo tiempo, fray Pedro de Gante, que temía el incumplimiento de las Leyes Nuevas por parte de los encomenderos ${ }^{54}$, solicitaba que no se consintiese tener indios como esclavos en las minas, porque los mineros los encerraban y de ese modo les impidían reclamar su libertad conforme a las nuevas ordenanzas. Además, proponía que cualquier

${ }^{48}$ DE La Puente, José, cit. (n. 14), p. 23 s.

${ }^{49}$ La posterior pacificación de la Gasca alteró el espíritu de la ley, que efectivamente abolía las encomiendas, y afirmó la autoridad de la Corona, reteniendo el poder de los encomenderos. Ibíd.

50 "Vistas las cartas y provisiones y las ordenanças de sus magestad todos los conquistadores y pobladores estantes y abitantes se escandalizaron viendo las dichas ordenanzas [...] del capitulo que dize que no hereden los hijos de los conquistadores ni sus mujeres los yndios de repartimiento de su magestad les tenya hecho merced que heredarian agravianse por esta revocación [...] el capitulo que dize que no se hechen yndios a las minas ny se saque oro dellas deste se agravian mas aun que de todos porque generalmente toca a todos asi soldados como conquistadores estantes y abitantes que toda la governaciónlen el capitulo que todos los esclavos yndios sean libres haviendo su magestad llevado sus quintos e derechos reales tambien se agravian desto porque toca a todos". Archivo General de Indias, Alteraciones en el Perú con los Pizarro, Almagro y otros (1543, sign. Patronato, 185, R. 38), Bloque 3, fs. 1-2 [acceso en línea: http://pares.mcu.es].

${ }^{51}$ Tameme es una palabra que proviene del lenguaje náhuatl tlamama, que significa cargar.

${ }^{52}$ Archivo General de Indias, Antonio de Mendoza, virrey de México: servicios de los indios (circa 1544, sign. Patronato, 189, R. 70), fs. 1-2 [acceso en línea: http://pares.mcu.es].

${ }^{53}$ Antonio de Mendoza se mostró renuente a prohibir los servicios personales en las minas y en las casas de los españoles. Le abrumaba tasar a los indios nuevamente y parecía convencido del efecto negativo que esto tendría en la prosperidad de las minas de plata en la Nueva España. Archivo Histórico Nacional de España, Repartimientos de los servicios personales de indios (1549, junio 10, San Juan de Huastepec, sign. Diversos-Colecciones, 23, N. 31), fs. 1r-1v [acceso en línea: http://pares.mcu.es].

${ }^{54}$ En una carta al rey Carlos, fray Pedro de Gante escribía: "[...] se mueren de hambre y se despueblan por el demasiado trabajo, bien creo que si las cedulas de Vuestra magestad que aca ha embiado en su favor, fueran complidas y los governadores y Justicias no las disimulasen que vendría y uviera venido gran bien a esta gente [...]”. Archivo Histórico Nacional de España, Carta de Pedro, cit. (n. 27), f. 1r. 
pedido de libertad fuese resuelto de inmediato, sin retardar la justicia ni incurrir en procesos ordinarios ${ }^{55}$.

\section{LOS INDIOS COMO PERSONAS MISERABLES}

\section{La pretensión del obispo de Chiapa, fray Bartolomé de las Casas}

Desde el momento en que fray Bartolomé aceptó el cargo de obispo de Chiapa, demostró que asumiría un papel activo en el cumplimiento y ejecución de las Leyes Nuevas. Para Las Casas, el orden provenía de la ley y de la sujeción al rey y a las leyes. Se quejaba de la desobediencia de las autoridades locales a la autoridad suprema del monarca y del desacato a sus leyes, e incluso de su temeridad para llegar aún más lejos, en contra de la razón natural y de las leyes divinas. Cuando llegó a la provincia de Chiapa y tomó posesión de su cargo como obispo, Las Casas consideró que debía tomar medidas drásticas para desalentar los agravios contra los indios. Así, en su primera carta pastoral de 20 de marzo de 1545 en la Ciudad Real ${ }^{56}$, utilizó los cánones eclesiásticos para exigir a los vecinos que denunciasen los pecados públicos que conocían, o que podían conocer, que se cometían contra los indios y sus propiedades, o abusos con la tasación del tributo y el pago por sus trabajos o servicios, o cualquier otro agravio, violencia o menoscabo hacia sus personas - "[...] todo lo cual toca y pertenece a ser opresas y afligidas y menoscabadas estas gentes" ${ }^{57}$; so pena de excomunión: "E si sabéis o habéis oído decir, o es fama dello, que las miserables personas, como son los indios naturales destas tierras e provincias o otras personas viudas, huérfanos y pupilos, todos los cuales son de nuestro fuero y jurisdicción, han sido y son opresas y agraviadas, usurpándoles su...], poniéndoles miedos o amenazas, o poniendo manos en ellos porque no se vengan a quejar ante nos o ante la justicia [...]"58. En esta carta firmada ante notario por fray Bartolomé de las Casas, Episcopus Civitatis Regalis, el obispo de Chiapa declaraba a los indios ser personas miserables, y justificaba en el derecho canónico su protección eclesiástica: "las miserables personas, como son los indios [...] son de nuestro fuero y jurisdicción”. Meses más tarde, Las Casas recurrió nuevamente a los cánones en un requerimiento dirigido al presidente y a los oidores de la audiencia de los Confines, que suscribió junto con los obispos de Nicaragua, Antonio de Valdivieso, y de Guatemala, Francisco Marroquín, el 19 de octubre de 1545. En aquel manuscrito aparecía una selección de fundamentos morales y jurídicos para caracterizar a los indios como personas miserables, y para justificar la jurisdicción

55 “[...] que no se consienta que los mineros los tengan encerrados para que no puedan venir a pedir libertad, e que al que la pidiere brevemente se le haga justicia sin dar lugar a pleytos ordinarios con ellos proveyendo persona que brevemente les haga justicia yendo por las minas y desgraviandoles [...]”. Ibíd., f. 1v.

${ }^{56}$ Las Casas introducía su carta pastoral como obispo de la Ciudad Real de la provincia de Chiapa y de las provincias de Yucatán, y se proclamaba "protector de los indios vecinos y naturales" de dichas provincias. DE LAS CASAS, Bartolomé, Proclama a los feligreses de Chiapa, en Obras completas: 13 Cartas y Memoriales (Madrid, Alianza Editorial, eds. Paulino Castañeda, Carlos de Rueda, Carmen Godínez e Inmaculada de la Corte, 1995), p. 193.

${ }^{57}$ Ibíd., p. 196.

${ }^{58}$ Ibíd., p. 195. 
de sus causas en el fuero eclesiástico ${ }^{59}$. Los tres obispos, Bartolomé de las Casas, Francisco Marroquín y Antonio de Valdivieso, desarrollaron una exposición del derecho canónico y de la doctrina jurídica canónica, que configuraba el derecho de los indios al trato privilegiado de las personas miserables: "[...] los dichos obispos pueden según derecho conocer y determinar de las causas tocantes a los indios naturales de las provincias de sus obispados como de causas de personas miserables y muy miserables privilegiadas por la ley divina y por la santa y universal iglesia, en especial de los agravios, y fuerças y opresiones que se les hazen [...]" ${ }^{60}$. Su argumentación jurídica mostraba una conexión entre las normas canónicas y las obligaciones de la moral cristiana, sin olvidar de mencionar el deber de evangelización adquirido con la recepción de los títulos del descubrimiento ${ }^{61}$. A los pocos días de su primer requerimiento, y luego del desistimiento a dicha solicitud de parte del obispo de Guatemala, Francisco Marroquín, los obispos de Chiapa y de Nicaragua insistieron con sus peticiones en un segundo requerimiento. El nuevo documento de 22 de octubre de 1545, más corto que el anterior, insistía en su pedido de mandar a hacer "provisiones para los alcaldes y justicias", declarando que el conocimiento y protección de las causas de los in dios pertenecían por derecho al fuero eclesiástico, por ser t o d o s ellos personas miserables ${ }^{62}$. Es probable que Las Casas no haya dudado de su competencia como juez eclesiástico para atender las causas de las personas miserables, según lo establecido en los cánones eclesiásticos, pero si mostró claramente que dudaba del respaldo a su competencia por parte de las autoridades civiles. Anticipándose a esa posibilidad, el obispo Las Casas estimó conveniente amenazar a los oficiales de la audiencia de los Confines con la excomunión, si le impedían el ejercicio de su jurisdicción ${ }^{63}$. Como había de esperarse, el resultado

59 “[...] uno de los casos que pertenecen de derecho y según los cánones sacros a los obispos y juezes eclesiásticos [...] es en las causas de las personas miserables y señaladamente cuando son opresas y agraviadas, porque estas tales personas tienen la iglesia debaxo de su proteción y anparo y de derecho divino es obligada a las manparar y defender y de conocer de sus injurias y vexaciones e injusticias y determinar y hazer justicia en ellas [...]". Assadourian, Carlos, Fray Bartolomé de las Casas obispo: la naturaleza miserable de las naciones indianas y el derecho de la Iglesia. Un escrito de 1545, en Historia Mexicana, Colegio de México, $40 / 3$ (1991), p. 440.

${ }^{60}$ Ibíd., p. 445.

${ }^{61}$ Ibíd., pp. 440-446.

${ }^{62}$ Esta petición demuestra que Las Casas preveía posibles impedimentos o rechazos a su jurisdicción, por eso buscaba provisiones de las autoridades civiles: "Lo $4^{\circ}$ que Vuestra alteza declare pertenecer al cognoscimiento y protecion de las causas de las miserables personas como son estas gentes indianas al juicio eclesiastico y enbien sus provisiones sobre ello a los alcaldes y justicias de los pueblos ciudades villas y lugares para evitar escandalo, porque como son idiotas y saben poco ó nada de lo que deven a Dios y a su iglesia pensaran que yo me entremeto en usurpar la jurisdicción real la qual yo defiendo y entiendo defender y reverençiar en quanto yo pudiere". Archivo Histórico Nacional de España, Requerimiento obispo, cit. (n. 47), fs. 1v-2r.

63 "Lo qual haziendo y mandando vuestras altezas harán lo que son obligados de derecho al favor de la santa madre iglesia como dicho es y estorvarán muchos daños y injusticias que a los dichos indios vasallos del rey se les hacen [...]. Pero sino lo hizieren lo qual no creemos, protestamos de hazer en ello todo aquellos que aliaremos que devemos hazer de derecho. Y acuérdense vuestras altezas que no menos incurrirán el presidente y oidores desta real audiencia en la dicha escomunión papal ipso facto [...]". Assadourian, Carlos, cit. (n. 59), pp. 445-446. La amenaza de excomunión, sin embargo, no impidió que la audiencia rechazase el pedido de Las Casas, so pretexto de 
fue infructuoso. El 26 de octubre de 1545, la audiencia emitió su respuesta al segundo requerimiento de 22 de octubre firmado por Las Casas y Valdivieso. $\mathrm{Al}$ capítulo $4^{\circ}$ sobre la jurisdicción en las causas de los indios respondieron: " $\mathrm{Al}$ cuarto que ya esta proveydo que no a lugar" ${ }^{64}$. Esta respuesta pareciera haberse extrapolado de una provisión de la Corona de 13 de febrero de 1544, dirigida al obispo de Chiapa, rechazando previas peticiones suyas tales como la facultad para poner visitadores en su obispado, vigilar el tratamiento de los indios, estar presente en la tasaciones de tributos, y poder para incorporar en la cabeza del rey a los indios de las encomiendas que quedasen vacantes ${ }^{65}$. En realidad, el punto cuarto del requerimiento de 22 de octubre no debía extrapolarse con una provisión anterior, que no guardaba correspondencia con el fondo de la nueva pretensión de jurisdicción de Las Casas ni con su caracterización de los indios como personas miserables. El presidente Maldonado y los oidores de la audiencia de los Confines ni siquiera se molestaron en responder al primer requerimiento de 19 de octubre de 1545, firmado por los tres obispos de Chiapa, Nicaragua y Guatemala, porque desconocieron totalmente su autoridad para ejercer la jurisdicción eclesiástica en las causas de los indios: "por defeto de juridizion" ${ }^{66}$. Es más, la audiencia no daba explicaciones del supuesto defecto jurisdiccional con base en el derecho común o en el derecho indiano. La respuesta de la audiencia al segundo requerimiento fue leída al obispo Las Casas en su sede de la Ciudad Real, y en ella amenazaba al obispo con dar noticias al rey de su desacato a la jurisdicción civil, y de su comportamiento, que supuestamente constituía un intento de usurpación de funciones.

Es trascendente que ambos requerimientos, de 19 y 22 de octubre de 1545,

usurpación de la jurisdicción civil, como aparece en la respuesta de la audiencia a Las Casas de fecha 26 de octubre de 1545.

${ }^{64}$ Archivo General de Indias, Bartolomé de las Casas: vulneración dignidad episcopal, etc. (1545, sign. Patronato, 252, R. 10), f. 10 [acceso en línea: http://pares.mcu.es]. La respuesta fue leída en la audiencia delante de Las Casas el 26 de octubre por Diego de Robledo, pues no le quisieron dar copias gratuitas de la respuesta. Las Casas se quejaba de esto en una carta dirigida el príncipe Felipe el 9 de noviembre de 1545. Le decía, que no había recibido la respuesta de la audiencia por escrito conforme a su solicitud: "[...] que nos buelvan esta misma petición y requerimiento a la letra como va con la respuesta de vuestras altezas en ella misma". En lugar de eso, le dijeron que se quedarían con sus peticiones y que le harían los traslados a condición de que pagase cincuenta maravedís por cada hoja. Esto molestó mucho al obispo que se negó a pagar. Archivo Histórico Nacional de España, Carta de Fray Bartolomé de las Casas, Obispo de Chiapa, al principe Felipe, quejándose de la Audiencia de los Confines (1545, noviembre 9, Gracias a Dios, sign. Diversos-Colecciones, 23, N. 3), f. 4r [acceso en línea: http://pares.mcu.es]

${ }^{65}$ Assadourian, Carlos, cit. (n. 59), pp. 402 ss.

${ }^{66} \mathrm{La}$ respuesta al octavo capítulo concluía que Las Casas no tenía jurisdicción y que su pedido era una usurpación de la autoridad civil: "[...] esta audiencia siempre a respondido a lo que el dicho obispo de Chiapa y los demas obispos an pedido y en todo se a proveydo lo que a parecido que convenia a la buena governacion teniendo respeto al buen tratamiento conservación e ynstrucción delos naturales y en ninguna cosa se a ynpidido ny ynpidirá la libertad de la iglesia ny perturbado su juridizion antes el dicho obispo de Chiapa a procurado husurpar la de su magestad como parece por lo que en esta audiencia a pedido y procurado y a recevido y desto y del desacato que a thenydo se dara noticia a su magestad par que mande proveer como sea castigado y en lo que mas dize en sus requerimientos y amonestaciones ansi por defeto de juridizion [...]”. Archivo General de Indias, Bartolomé de las Casas: vulneración, cit. (25), f. 11. 
hayan sido hechos en colaboración entre los obispos fray Bartolomé de las Casas, fray Antonio de Valdivieso y Francisco Marroquín; aunque el 20 de octubre el obispo Marroquín optó, personalmente, por desistirse del primer requerimiento ante la audiencia ${ }^{67}$. El 25 de octubre de 1545, a pocos días de entregados los requerimientos al presidente Maldonado y a sus oidores, los obispos de Chiapa y de Nicaragua dirigieron una carta al príncipe Felipe, en la que mencionaban su actuación ante la audiencia y las razones que, como les parecía obvio, hacían imposible atender su pedido de jurisdicción sobre los indios: "[...] no hemos sacado fruto ninguno sino palabras porque ninguna provisión pueden dar que no sea contra maldonado presidente por los muchos indios que tiene abarcados y robados el y los que le tocan [...]"68. Explicaban que en su experiencia la justicia en la audiencia de los Confines era nula y existía impunidad, al punto que si nadie se acercaba a pedirles justicia era por temor a resultar agraviados con "su justicia". Hablando de su diócesis, Las Casas decía que estaba en aquellos reinos para pedir justicia y remedio, y para "desarraigar la tiranía” que agraviaba a los indios y oprimía a su Iglesia ${ }^{69}$.

Coincidimos con Carlos Sempat Assadourian, en que la defensa y la protección de los indios bajo la forma de la jurisdicción eclesiástica que Las Casas argumentaba en su carta al príncipe Felipe, aparecía justificada bajo la forma de $\mathrm{r}$ e m e d i o ("nosotros [obispos] a pedir y ellos [autoridades] a remediar"), aunque no nos parece que se haya tratado simplemente de un remedio de congruencia entre el nivel normativo y los órganos ejecutivos, como Assadourian afirma ${ }^{70}$, sino de un remedio para conseguir justicia a través del derecho y del cumplimiento de las leyes. Los obispos Las Casas y Valdivieso pedían que se encomendase a prelados virtuosos "la defensa y protección temporal" de los indios, para asegurar el cumplimento de las leyes ${ }^{71}$. Esta era una función característica de los protectores y defensores de indios. Otras razones que justificaron la pretensión del obispo de

${ }^{67}$ El trabajo de Carlos Sempat Assadourian, discute algunas ideas sobre la enemistad entre Las Casas y Marroquín. En su apéndice, publica el desistimiento del obispo Marroquín, ocurrido al día siguiente del requerimiento de 19 de octubre de 1545 que presentaron los tres obispos a la audiencia. Assadourian, Carlos, cit. (n. 59), pp. 446 ss.

68 "[...] aquí emos pedido y hecho con esta audiencia lo que nos a parecido que nosotros a pedir y ellos a remediar eran y eramos obligados y emos requerido y hecho las diligencias que según Dios creemos y debiamos hazer no hemos sacado fruto ninguno sino palabras porque ninguna provisión pueden dar que no sea contra maldonado presidente [...]". Archivo Histórico Nacional de España, Queja del obispo de Nicaragua de la Audiencia de los Confines (1545, octubre 25, Gracias a Dios, sign. Diversos-Colecciones, 23, N. 2), f. 2v [acceso en línea: http://pares.mcu.es].

${ }^{69}$ Ibíd., f. 1v.

${ }^{70}$ Assadourian, Carlos, cit. (n. 59), p. 418 s.

71 "Y porque la guarda destas ordenanzas y complimiento y execucion dellas y las otras provisiones reales, tenemos larga experiencia questos tyranos de ministros del rey no [sic] sino a muy pocos y mas que muy pocos, no las an complido ni las an de complir, porque parece quel diablo se les reviste en las entrañas de ambición y codicia [...], dezimos y osamos decir a Vuestra alteza y a su magestad lo diremos que para que todo lo que su magestad manda se cumpla fielmente, y estas gentes no acaben de perecer que la defensa y proteción temporal dellos y la execucion delas leyes y ordenanzas y provisiones hechas y por hazer, se a de encomendar y cometer alos prelados no a todos, sino alos que han dado o diesen muestra de no querer ser vivos sino hazer lo deben a Dios y a su rey, y no es mucho que se 
Chiapa incluyeron el acceso a la doctrina; el favor y la defensa a los nuevos en la fe, y el deber de la Santa Iglesia Católica de proteger a las personas miserables ${ }^{72}$. El objeto de su pretensión de jurisdicción era librar a los indios de los continuos agravios $^{73}$.

Las Casas pensaba que el desorden en las Indias provenía, en parte, del desacato a las ordenanzas del rey: "[...] todo procede de no aver justicia [...] no viendo que ay aca justicia ni fidelidad ni temor que se tenga al rey [...]"74, pero, sobre todo, de la ambición y la codicia que movía a muchos españoles. Años más tarde, insistiría en que le hacía mal a las Indias no tener justicia y estar tan "remotas a los ojos del principe que las ha de gobernar"75.

\section{Las "miserables personas" que eran los indios en Bartolomé de las Casas}

El grueso de la argumentación de Las Casas en el requerimiento de 19 de octubre de 1545, va referido a la conveniencia de la jurisdicción eclesiástica para remediar los agravios contra los indios, porque eran personas miserables. Su argumentación jurídica era un avance notable en la defensa lascasiana de los indios, porque conectaba el derecho canónico del ius commune con la justicia indiana. Fray Bartolomé caracterizaba a los indios como gente oprimida por su estado de necesidad y desamparo, y hacía un llamado a su derecho de protección: " $Y$ como todos los indios naturales de todas estas Yndias del mar Océano, ansí señores y grandes como chicos y basallos, sin sacar uno ni ninguno, sean las más miserables y más opresas y agraviadas $y$ afligidas y desmanparadas personas que más injusticias padezcan $y$ mayor necesidad tengan de manparo, defensión y proteción [...]"76. Describía a los indios como personas, en general, oprimidas, agraviadas, afligidas, desamparadas y dignas de compasión. Conforme al derecho canónico, Las Casas planteó una definición de la persona miserabilis que, a su juicio, se hacía manifiesta en los indios: "[...] miserable persona es aquella que por sí misma no puede defender sus causas e pedir su justicia conviene a saber por defeto de su pobreza o pusilaminidado de ciencia o experiencia o de miedo que tenga o de otra cualquiera inpotencia. [...] es manifiesto a todo el mundo quantas necesidades y defetos padecen cada día y sienpre

les encomienden los cuerpos pues que tienen sobre si a cuestas encomendadas las animas". Archivo Histórico Nacional de España, Queja del obispo, cit. (n. 68), f. 2r.

${ }^{72}$ Assadourian, Carlos, cit. (n. 59), pp. 443-445.

73 "[...] se estorvarán muchos daños e injusticias que a los dichos indios vasallos del rey cada dia les hazen [...] impedirán muchos desacatos y desobediencias y escándalos que se podrían hazer y suceder a los dichos obispos y sus iglesias [...]”. Assadourian, Carlos, cit. (n. 59), p. 445.

${ }^{74}$ En su necesidad de justicia, fray Bartolomé empezó a formarse la idea de que haría más provecho en la provincia de la Vera Paz, como le llamaban los frailes dominicos a Tezulutlán, que, en Chiapa, y especulaba sobre su posible nuevo obispado: "[...] que alli aya justicia y obediencia al rey y las ordenanzas nuevas se guarden, y sino no quiero tener en mi obispado un pueblo español que tenga yndios porque todos son tyranos y ninguno se salva”. Archivo Histórico Nacional, Carta de Fray Bartolomé, cit. (n. 64), fs. $2 \mathrm{v}-4 \mathrm{v}$.

${ }^{75}$ Carta de Bartolomé de las Casas a Domingo de Soto tratando de persuadirle que plantee al emperador el remedio del gobierno de las Indias. DE LAS CASAS, Bartolomé, De regia potestate, cit. (n. 15), p. 120.

${ }^{76}$ Assadourian, Carlos, cit. (n. 59), p. 440. 
cada una y todas destas gentes indianas naturales destas Yndias [...]"77. En primer lugar, Las Casas logró, de manera extraordinaria, que trascendiera la idea de que la miserabilidad abarcaba a todos los indios -"miserables personas como son estas gentes indianas" $-{ }^{78}$, asociándolos a todos por padecer las mismas necesidades y los mismos defectos; son muy pobres, simples y pusilánimes, y merecen compasión del prójimo: "[...] porque la misma naturaleza mueve a los hombres a que dellas se conpadezcan [...]"79. La Corona, más adelante, adoptó estos presupuestos lascasianos en su legislación a favor de los indios como personas miserables ${ }^{80}$. En segundo lugar, Las Casas percibió la fragilidad de su estado condicionado por la cultura jurídica española con la que los indios no tenían ninguna familiaridad; desconocían el derecho, el proceso y sus defensas o remedios ${ }^{81}$. Además de no tener conocimiento ni experiencia del derecho, Las Casas explicaba que los indios sufrían el abuso de las autoridades cuando las buscaban para remediar sus problemas ${ }^{82}$, y que existía temor entre ellos para quejarse o pedir justicia ${ }^{83}$. El obispo de Chiapa

${ }^{77}$ Ibíd., pp. 440-441.

${ }^{78}$ En efecto, la flexibilidad del concepto de las miserabiles personae en el ius commune, permitió la asimilación de nuevos grupos de personas miserables. Esto era perfectamente compatible con la intención de la ley imperial romana, que buscaba proveer de una justicia adecuada a las circunstancias de los grupos vulnerables, sobre todo de los pobres. Por lo cual, el razonamiento detrás de la elegibilidad de las personas miserables no estuvo sometido a criterios fijos, ni dependió absolutamente de ciertas características subjetivas como aquellas que distinguían a los sujetos en pobres, enfermos, viudas, ancianos, menores, huérfanos o incapaces.

${ }^{79}$ Assadourian, Carlos, cit. (n. 59), pp. 441-442.

${ }^{80} \mathrm{La}$ ley 13 de la Recopilación de las Leyes de Indias, señalaba una ordenanza de 1582 del rey Felipe, desde Lisboa, en la que exigía a los arzobispos y obispos, amparar a los indios por ser personas miserables. "Los indios son personas miserables, y de tan débil natural, que fácilmente se hallan y oprimidos, y nuestra voluntad es que no padezcan vejaciones, y tengan el remedio y amparo conveniente por cuantas vias sean posibles, y se han despachado muchas cédulas nuestras proveyendo que sean bien tratados, amparados y favorecidos, las cuales se deben ejecutar sin omisión, disimulación ni tolerancia, según está encargado á nuestros ministros Reales. [...] dispongan por lo que les toca en las visitas que hicieren de sus diócesis y en todas las demás ocasiones con toda atención y vigilancia, lo que convenga para evitar la opresión y desórdenes que padecen los indios [...]”. DE LA GUARDIA, Miguel, Las leyes de Indias (Madrid, Establecimiento Tipográfico de Pedro Núñez, 1889), I, pp. 121 ss.

${ }^{81}$ Assadourian, Carlos, cit. (n. 59), p. 441.

${ }^{82}$ Las Casas escribió en su requerimiento: "[...] los mismos alcaldes de las ciudades, villas y lugares como quiera que son los mayores tiranos [...] que más agravios y crueldades e injusticias les hazen [...]. Y si a ellos se van a quexar de los daños y tormentos [...] el consuelo y remedio que en ellos hallamos hazellos cruelmente açotar y atormentar porque aquellos ni los que tiranizados tienen, no osen buscar ni aun pensar buscarlo sublevación [...] ansi que carecen totalmente de justicia [...]”. Ibíd., p. 442.

${ }^{83}$ Esta idea la compartía el obispo de Guatemala, quien caracterizó a los indios como gente "pobre y medrosa", que no solía pedir nada. Pensaba que la Corona debía mandar a los oidores de la audiencia de los Confines a visitar los territorios de su obispado, y acercarse a los indios para preguntarles lo que les convenía "[...] y conviene mucho y es un artículo muy esencial que siempre anden los oydores visitando la tierra y deshaziendo agravyos que es una gente tan pobre y tan medrosa que sino van a sus casas ales preguntar lo que les conviene no se les da nada que se pierda todo con aver dicho esto he descargado algo de mi conciencia [...]”. Archivo Histórico Nacional de España, Carta del obispo de Guatemala solicitando más indios, (1547, setiembre 20, Guatemala, sign. Diversos-Colecciones, 23, N. 15), f. 3v. 
no fue el único en opinar de esta manera. El fraile franciscano, Pedro de Gante, afirmaba que no faltaban ocasiones en que los indios, a costa de su ignorancia, eran fácilmente instigados por los españoles a pleitear, incluso contra otros indios ${ }^{84}$. Del mismo modo, Diego de Torres, cacique de Tunja en Nueva Granada, decía, en un lenguaje muy parecido al de fray Bartolomé, que los indios padecían como personas miserables, cuando hacían el intento de reclamar los agravios en su contra: "[...] como no saben los pobres naturales manifestar el agravio y engaño que asi se les ha hecho carecen de remedio y si algun desbenturado principal dellos se ha movido a pedirlo lo han destruido y asolado por lo qual padecen como personas miserables finalmente ovejas mudas"85.

Las Casas hacía alusión constante a la opresión, a los agravios y al desamparo de los indios. Reclamaba su estado de indefensión frente a los abusos, y el abandono de las autoridades locales y de las justicias [jueces]: "[...] injurias, angustias $e$ injusticias daños y menoscabos, cautiverios y calamidades an pasado y oy padecen sin aver uno ni ninguno que por ellos aya buelto ni le haya defendido ni oy por ellas buelva ni las defienda, antes las mismas justicias y ministros del rey an sido y son oy (sacando los que es razón sacar y estos son muy pocos y más que pocos) los más injustos y crueles tiranos para con ellas [...]" 86 . Su desprotección o abandono podía ocurrir por estar lejos de las audiencias, lo cual les impedía el acceso a la justicia, o por no tener quien los defienda ${ }^{87}$. Las Casas sostenía que la r a z ó n ge n e r a l que amparaba su competencia eclesiástica en las causas de los indios era su condición de miserables personas, desoladas, destituidas, indefensas, muy pobres y necesitadas de protección y auxilio: “[...] conviene a saber esta razón general de ser miserables personas y muy miserables, provamos la dicha conclusión de pertenecer las causas y defensas destas gentes y al juizio eclesiástico" 88 . Asimismo, argumentaba cuatro razones específicas para conocer las causas de los indios. La primera, porque carecían de

84 “[...] ya no saben sino pleytos, y los escrivanos bien llenos de negocios dellos, porque por no nada mueven pleytos "[...] porque se han hecho pleytistas y en letrados y procuradores y escrivanos e interpretes gastan lo que tienen [...]”. Archivo Histórico Nacional de España, Carta de Pedro, cit. (n. 26), f. 1v.

${ }^{85}$ El cacique Diego de Torres, describía un caso de agravio en contra de un grupo de indios de Nueva Granada: "[...] que ay pueblo de indios que no tiene setenta tributarios y que en cada un año paga valor de mas de tres mill pesos de buen oro y tienenlo esto por flor y gran azaña siendo manifiesto robo y contra lo que Vuestra magestad tiene mandado y este daño y perjuizio a redundado de las dichas visitas que se han hecho porque en ellas han engañado a los visitadores y a los miserables naturales haziendoles dar copias de indios mas de los que tienen no theniendo la terçia parte de lo que les han hecho pareçer en las dichas visitas [...]”. Archivo General de Indias, Conversión, vejaciones y trabajos de indios: Nueva Granada (1584, sign. Patronato, 231, N. 6, R. 5), 2.

${ }^{86}$ Assadourian, Carlos, cit. (n. 59), p. 441.

87 "[...] porque en estas tierras ninguna justicia ay de su Magestad que las valga ni defienda comúnmente en los pueblos máxime donde no estan las reales audiencias [...]”. Ibíd., p. 442.

88 "Consiguiente cosa parece y asi es sin aver duda alguna de hecho y de derecho estar todas estas indianas gentes especialisimamente so la protección y anparo de la iglesia y que al juizio eclesiástico pertenece inmediatamente conocer y determinar sus causas y hazerle todo cumplimiento de justicia, defender sus vidas y libertad de todas y qualesquier personas, desazer sus agravios [...], como a misérimas, paupérrimas inpotentísimas para se defender y de todo consuelo, auxilio y favor y socorro desolatísimas y sin conparación desmanparadas y destituidas personas [...] ”. Ibíd., p. 442. 
justicia, "ninguna justicia ay de su Magestad que las valga", y la segunda, por los "pecados de tiranías injusticias" de los españoles contra los indios (capítulos licet ex suscepto; ex tenore de foro competenti y novit de iudiciis) ${ }^{89}$. La tercera razón era por causa de la fe, "impedida y afrentada", y descuidada por los encomenderos (capítulos irrefragabili de oficio ordinarii; licet heli de simonia; ex communicationis; qualiter et quando de accussationibus título 2; prohumani de homicidio en el libro 6; y el capítulo duo título 96) ${ }^{90}$. En este punto, Las Casas atacaba los servicios personales y las guerras que alejaban a los indios de la doctrina. La cuarta razón reconducía a la primera: por no existir justicia con los indios, los prelados y pastores de la Iglesia, "[...]que con mas benignidad, blandura y suavidad suelen tratar las semejantes personas [...]", debían recibir sus causas ${ }^{91}$.

El maltrato que los indios recibían de los encomenderos, los servicios personales y el trabajo excesivo que pesaba sobre ellos para cumplir con el tributo, fueron factores decisivos en la percepción de Las Casas sobre el desamparo de los indios: "[...] por la causa de los trabajos y vida infernal que en lo susodicho padecen y por los otros muchos malos tratamientos que se les hazen, sin tener dellos como dicho es alguna señal ni parte de alivio [...]"92. Las Casas comprobó, también, que existía un desamparo jurídico producto del abandono de la justicia. El cacique de Tunja, Diego de Torres, lo corroboraba desde su propia experiencia. Decía que los indios eran míseros y desventurados porque los encomenderos desobedecían las leyes del rey y cometían abusos en su contra ${ }^{93}$. El cacique de Tunja llegó hasta el rey para explicarle que las justicias no cumplían con su deber y que los indios quedaban abandonados a su suerte. En su memorial al rey, le persuadía para que se diese cuenta de que él mismo, como gobernante, era víctima del engaño de sus justicias y de sus encomenderos, y que de ese modo resultaba siendo un tercero agraviado en las causas de los indios ${ }^{94}$. Además, Las Casas notaba el desamparo moral de los indios. En una carta dirigida a Domingo de Soto, Las Casas le comunicaba

\footnotetext{
${ }^{89}$ Ibíd.

${ }^{90}$ Ibíd., pp. 443-444.

${ }^{91}$ Ibíd., p. 444.

${ }^{92}$ Ibíd., p. 443.
}

${ }^{93}$ En su famoso memorial al rey Felipe II de 1584, el cacique Diego de Torres se refirió al infortunio de los indios y les llamó "míseros indios, miserables naturales, pobres, desventurados, personas miserables, ovejas mudas, miserables en nuestras personas y vidas”. Sobre el incumplimiento de las leyes, argumentaba sobre un caso de agravio por el pago de tributos: "Vuestra magestad tiene ordenado y mandado sobre los tributos que han de pagar los naturales de aquellas partes a sus encomenderos sea de manera que no reciban para ello agravio alguno para que entiendan que despues que estan debajo de vuestro real amparo y gobierno son mejor tratados que en tiempo de sus caciques y señores of fueron para que con mas amor tomen las cosas de nuestra Santa fee católica no se ha hecho conforme a vuestra real intención por que en las visitas y tasaciones que se han hecho hasta aqui de lo que an de dar y tributar han sido muy engañados y agraviados los miseros indios [...]". Archivo General de Indias, Conversión, vejaciones, cit. (n. 85), f. 1.

94 “[...] a Vuestra magestad le cabe en esta causa su parte como le cabe a aquellos míseros naturales y esto es averiguado que de dos que padecen en esta causa es el uno vuestra magestad y el otro nosotros miserables por que esto se vee por experiencia con los juezes que vuestra magestad ha embiado para remediar aquella tierra nunca hallan otro culpado ni delincuente sino es a vuestra magestad por que todo se haze a costa y gasto de vuestras reales rentas y no averiguan ni remedian cosa alguna. $Y$ 
sus ideas acerca del remedio general de las Indias, que era la liberación completa de los indios y su sujeción directa al rey. Asimismo, le comentaba su desamparo, porque padecían angustias y estragos ${ }^{95}$.

Al mismo tiempo que Las Casas buscaba soluciones para la jurisdicción, también mostraba su preocupación por encontrar la equidad en el orden social entre españoles e indios. Sabía que mientras las circunstancias causantes de los agravios continuasen -las encomiendas, los servicios personales y los tributos desmedidos-, poco sería el avance social en beneficio de los indios: "[... la estada delos españoles en las yndias es medio ordenado para el bien delos yndios como a fin, [...] y no aya tantos que coman y no trabajen y muchos se tornen a sus oficios pues era oficiales $y$ dexen de ser cavalleros con los sudores y sangre de los miserables y afligidos hombres [...]"96. La extraordinaria propuesta lascasiana para acabar con aquella miseria, era aplicar un remedio de reingeniería social, que reestructurase las comunidades de labradores en comunidades de trabajo mixtas de españoles e indios ${ }^{97}$. Si bien se trató de un plan utópico, como señala Lewis Hanke ${ }^{98}$, las Casas lo promovió en varias oportunidades, en su Memorial de remedios para las Indias de 1516, en sus Conclusiones sumarias sobre el remedio de las Indias de 1542, y en un memorial de 1549 dirigido al Consejo de Indias.

\section{La teoría de los indios como personas miserables}

Las aproximaciones a la teoría de los indios como personas miserables han variado en carácter y en perspectiva a lo largo del tiempo. Sin embargo, todos los estudios convergen, ineludiblemente, en la conocida institución de la persona

vienen a cargar por otra parte sobre el segundo paciente que son los miserables naturales que nunca alcanzan remedio ni justicia [...]". Ibíd., f. 10.

${ }^{95}$ En su carta a Domingo de Soto, Las Casas repudió el maltrato a la dignidad de los indios, y mencionó que tomaría muchos hombres y muchos años más, remediar los pecados de España y calamidades de las Indias, "[...] las muertes y estragos, angustias e intolerable vida de los desamparados indios [...]. Y plugiese a Dios no los estimasen en menos que a chinches?". Carta a Domingo de Soto. Archivo General de Indias. Guatemala, 52. Publicada por M. Bataillon, en Bulletin Hispanic, 56 (154), pp. 384-387 y reproducida por V. Beltrán de Heredia, Domingo de Soto (Madrid, 1961), pp. 638-641, que coloca la fecha 1549. LAS CASAS, Bartolomé, De regia potestate, cit. (n. 15), p. 121. Un siglo más tarde, el canonista y obispo Gaspár de Villaroel, señalaría la "soledad, desamparo y desdicha" como características de las personas miserables, y que había de considerarse como tales a quienes se hallasen en condiciones semejantes. Duve, Thomas, Algunas observaciones acerca del modus operandi y la prudencia del juez en el derecho canónico, en Revista de Historia del Derecho, 35 (2007), p. 216

${ }^{96}$ En un memorial dirigido al Consejo de Indias en 1549, Las Casas trató de explicar la manera en que el desamparo social de los indios podía combatirse: "[...] mirar que los yndios no son obligados a perecer todos y a consumirse por dar de comer alos españoles [...] buscando y arrancando los yndios para ellos los tributos queden desmanparados y al cabo de hambre mueran sus mugeres e hijos". Archivo General de Indias, Fray Bartolomé de las Casas: libertad de los indios: Guatemala (Probable 1549, sign. Patronato, 252, R. 9), 3.

97 “[...] Y por esto muchas vezes digo y suplico en este real consejo que la verdadera población y remedio de aquellas yndias consiste en enbiar labradores gente llana y trabajadora que coma y sea rica y abundante con sus pocos trabajos [...]”. Ibíd., 3.

${ }^{98}$ Lewis Hanke dice que se trató de una propuesta revolucionaria: "this represents a fresh and indegenous Spanish Renaissance attitude”. HANKE, Lewis, cit. (n. 38), p. 50. 
miserabilis del ius commune, con antecedentes en el derecho romano. Vale la pena señalar, que así como el derecho, llámese europeo o indiano, "no preveía una respuesta inequívoca al planteo acerca de la jurisdicción de la Iglesia sobre las personas miserables"99, como afirma Thomas Duve, el concepto jurídico de la persona miserable tampoco fue inequívoco, sino de carácter flexible y de interpretación abierta. Los primeros debates sobre los indios como personas miserables en el Derecho Indiano, nacieron precisamente en el ámbito de la jurisdicción. Paulatinamente, se desarrollaría la base doctrinaria de los canonistas y los juristas de la segunda mitad del siglo XVI y del siglo XVII que, bajo ciertos parámetros, admitió la competencia del fuero eclesiástico en las causas de los indios ${ }^{100}$. El Primer Concilio Provincial Mexicano (1555), que reunió a los prelados mexicanos, anotaba en el capítulo XCII del Concilio que los indios merecían un trato considerado "[...] que son nuevos en la fe y que como tiernos y flacos con benignidad han de ser tratados [... $]^{101}$. El jurista castellano Gregorio López consideraba que la protección especial de los indios en el fuero eclesiástico era razonable por ser nuevos en la fe; aludía, también, a la lejanía de las Indias: "[...] y es en las Indias, $y$ partes muy remotas, de donde sin gran dificultad, y sin esperanza de oportuno remedio, no se podría ocurrir al Rey, ò al Superior [...] y desagraviar a los miserables tyranizados, y oprimidos; que en tal caso el Obispo ò Juez Eclesiástico podrá hacerlo por la dilación, distancia o imposibilidad [...]"102. El obispo de Popayán, Feliciano de la Vega, aseguraba que los indios eran personae miserabiles con menor poder que otros y merecían la competencia eclesiástica subsidiaria ${ }^{103}$, y el obispo Alonso de la Peña Montenegro explicaba que los indios padecían maltrato y eran admitidos, subsidiariamente, por los obispos por estar en tierras remotas ${ }^{104}$. Juan de Solórzano señalaba que los indios, por su condición miserable y humilde, debían gozar de privilegios iguales a los de las personas miserables, entre ellos los menores y los rústicos: "[...] por su miserable, humilde y atendida condición están mandados amparar por infinitas Cédulas, y Ordenanzas [...] Por la misma causa gozan de todos los privilegios de rústicos, y menores [...]"105. Nótese la equivalencia

${ }^{99}$ Duve, Thomas, cit. (n. 95), p. 199.

${ }^{100}$ Conforme a la revisión hecha por Thomas Duve sobre la persona miserabilis en el derecho canónico indiano, hubo al menos cierta coincidencia entre los canonistas sobre el acceso de los indios a la jurisdicción eclesiástica en las Indias, por estar en tierras alejadas del rey. Ibíd., pp. 212-221.

${ }^{101}$ En el capítulo XCII del Primer Concilio Provincial Mexicano aparece el texto que Jorge Traslosheros transcribe, refiriéndose a los indios como nuevos cristianos en la fe católica, a quienes debe otorgarse un trato privilegiado: "[...] mirando su miseria y teniendo en consideración que son nuevos en la fe y que como tiernos y flacos con benignidad han de ser tratados y corregidos queremos no obligarlos a otras penas, más de aquellas que el derecho canónico por ser cristianos les obliga y a los que arbitraria y benignamente los prelados y jueces eclesiásticos por su desobediencia les pareciere y quisieren obligar y condenar". TRASLOSHEROS, Jorge, El tribunal eclesiástico y los indios en el arzobispado de México, hasta 1630, en Historia Mexicana, El Colegio de México, 51/3 (2002), pp. 485-516, esp. p. 493.

${ }^{102}$ Duve, Thomas, cit. (n. 95), p. 214.

${ }^{103}$ Ibíd.

${ }^{104}$ Ibíd., pp. 218 s.

${ }^{105}$ DE Solórzano, Juan, Política indiana (Madrid, Imprenta Real de la Gazeta, ed. corregida 
sutil que Solórzano hizo de la condición de miserable entre los indios y los menores y rústicos, que les proporcionaba iguales privilegios, mas no atribuía a los indios la condición de menores.

Tratándose de autores más cercanos a nuestro tiempo, tenemos a Paulino Castañeda que recoge la explicación de Constantino Bayle acerca de cómo debía entenderse la legislación indiana aplicada a los indios: "[...] es considerar a los indígenas como menores, incapaces de administrarse por si, y más de defenderse jurídicamente de los atropellos a que su debilidad los exponía" ${ }^{106}$. Castañeda señala que la Corona resentía el incumplimiento de las ordenanzas hechas en contra de los servicios personales, y esa era la carga injusta que constituía la opresión de los españoles: "Hay muchos intereses creados; se tapan unos a otros y resulta que los indios miserables quedan sin defensa, cargas y servicio que violentamente se les impone, y porque según buena teología uno de los pecados que más llaman ante Dios [...] es la opresión a los pobres, indefensos y humildes por los poderosos" 107 . Abelardo Levaggi, que analiza el desamparo en la práctica del derecho, propone el presupuesto de la "incapacidad relativa de hecho" como una característica de los indios s e m e j a n t e a la de los menores, alegando que dicha afectación a la capacidad plena del indio estuvo relacionada con su madurez: "fueron afectados, como antaño, por una incapacidad relativa de hecho, semejante a la de los menores, y necesitada, por lo tanto, de una representación legal para actuar de derecho "108. Francisco Cuena destaca un acento particular en la noción de miserabilidad, que desde su establecimiento en Roma había tenido un carácter individual o privado, ${ }^{109}$ pero que asumió un carácter colectivo para los indios en el derecho indiano. Cuena estima que quizás los indios fueron considerados como personas miserables en razón de una "acumulación retórica de causas de miserabilidad", entre las que predominó la consideración de menor del derecho romano ${ }^{110}$. Para Mauricio Novoa es claro que el indio no fue considerado pupilo carente de razón, dado que no estuvo exceptuado de la comisión de delitos ni pudo invocar en su defensa la ignorancia del derecho ${ }^{111}$. Novoa considera que la condición de miserable del indio pudo provenir de su estado (status) "definido en base a una serie de objetivizaciones en torno a su persona”: gentilidad y pobreza,

por Francisco Ramiro, 1776), II, p. 73.

${ }^{106}$ Castañeda, Paulino, cit. (n. 5), p. 263.

${ }^{107}$ Ibíd., p. 269.

${ }^{108}$ LeVAGgi, Abelardo, La protección de los naturales por el Estado Argentino (1810-1950): el problema de la capacidad, en Revista Chilena de Historia del Derecho, 16 (1990), pp. 445; 451.

${ }^{109}$ CuEna, Francisco, Especialidades procesales de los indios y su sustrato romanistico, en Anuario da Facultade de Dereito de Universidade A Coruña, 10 (2006), p. 159.

${ }^{110}$ Francisco Cuena explica que la consideración de menor parece reflejar más fielmente el sentido de la miserabilidad de los indígenas, al momento de extender algún privilegio asociado a la persona miserable. "De más está añadir que los m e n o r e s de los que hablamos son la prolongación o el equivalente en el derecho común y castellano de los minores viginti quinque annis del derecho romano". Ibíd., p. 160.

${ }^{111}$ NovoA, Mauricio, Derecho indiano y demandas y reivindicaciones indígenas: un enfoque para el lenguaje y la comunicación, en Razón y Palabra, 26 (2002) [acceso en línea en: http:// www.razonypalabra.org.mx/anteriores/n26/mnovoa.html]. 
según las leyes ${ }^{112}$. Eduardo Cebreiros considera que la doctrina jurídica asimiló a los indios como personas miserables debido a su incapacidad relativa ${ }^{113}$. Para Caroline Cunill, la categoría jurídica del indio como persona miserable fue un factor condicionante y determinante de su lugar en la sociedad y en la economía. Considera, por ejemplo, que el clero atribuyó al indio la categoría de pobre ${ }^{114}$. Rafael Sánchez-Concha sostiene que el carácter de miserable asignado al indígena fue la justificación utilizada para revestir de legitimidad la existencia de la república de indios. Explica que el término $\mathrm{m}$ is e r a b le tuvo la connotación de estado lastimoso, que infundió compasión y exigió el auxilio por parte del organismo social ${ }^{115}$. Asimismo, añade un contenido cultural a la noción de miseria, al referirse a las costumbres y al modo de vivir de los indios, desprovisto de p o l i c í a y ajeno a las costumbres de los españoles ${ }^{116}$.

\section{Conclusión}

En 1545, el obispo de Chiapa, Bartolomé de las Casas, declaró por primera vez que los indios eran personas miserables porque padecían agravios, opresión y desamparo. Tal estado era el resultado del maltrato de los encomenderos, de los servicios personales y de su abandono ante la administración de justicia. Además, porque eran pobres, simples y pusilánimes. Las Casas buscó actuar como juez eclesiástico en las causas judiciales de los indios de su obispado, pero fracasó en su intento de ejercer la jurisdicción. Fundaba su competencia y la legitimidad de la jurisdicción eclesiástica en el derecho canónico, que amparaba a las personas miserables, y en la necesidad que los indios tenían de obtener defensa, protección y justicia. También por causa de la fe, que hallaba obstáculo en los trabajos excesivos y en los servicios personales que los indios asumían para cumplir con el pago del tributo.

Algunos autores han desarrollado sus teorías jurídicas sobre los indios como personas miserables con base en supuestos jurídicos de minoridad o de incapacidad relativa. Se trata de propuestas que intentan equiparar algunas caracterizaciones de la institución de la persona miserabilis del ius commune, como las de menores o incapaces relativos, con ciertas características de la persona del indio. Sin embargo, tales teorizaciones suelen presentarse distantes del contexto histórico indiano que dio vida a la categoría jurídica de la persona miserable en las Indias.

Las Casas decía que el remedio general para las Indias consistia en alcanzar la libertad plena de los indios. En el paradigma lascasiano sobre la defensa de

\footnotetext{
${ }^{112}$ Ibíd.

${ }^{113}$ CeBreiros, Eduardo, La condición jurídica de los indios y el derecho común: un ejemplo del "favor protectionis", en "Panta rei": Studi dedicati a Manlio Bellomo, Condorelli, Orazio (ed. lit.), (Roma, Il Cigno Edizioni, 2004), p. 470.

${ }^{114}$ Cunill, Caroline, cit. (n. 1), p. 229.

${ }^{115}$ SÁNCHEZ-CONCHA, Rafael, De la miserable condición de los indios a las reducciones, en Del régimen hispánico. Estudios sobre la conquista y el orden virreinal peruano (San Pablo, Universidad Católica San Pablo, 2013), pp. 165-166.

${ }^{116}$ Ibíd., p. 169.
} 
los indios como personas miserables, la jurisdicción eclesiástica podría llegar a ser entendida como un remedio particular para las Indias, que le extendía un brazo al fuero secular de la justicia. El obispo Las Casas encontró oposición a su competencia como juez eclesiástico en las causas de los indios de su obispado, pero, su caracterización jurídica de los indios como personas miserables tuvo gran repercusión en el desarrollo doctrinario de esta institución en el derecho canónico indiano ${ }^{117}$. Ya en el mismo siglo XVI, la jurisdicción eclesiástica empezaba a ponerse al alcance de los indios, y continuaría al lado de la justicia secular durante el período virreinal ${ }^{118}$.

La consideración privilegiada y condescendiente de p e $\mathrm{r}$ o o $\mathrm{n} \mathrm{a} \mathrm{m}$ i s e r a b le que asociaba a todos los indios naturales de las Indias, fue una propuesta lascasiana a partir de la comprensión del concepto de la persona miserabilis contemplado en el derecho común. Esta idea también consiguió asimilarse al derecho canónico indiano. En la praxis judicial canónica, esto representó algunos ajustes procesales y la moderación en la aplicación del derecho a los indios ${ }^{119}$.

\section{BiBLIOGRAFÍA}

Fuentes

Alteraciones en el Perú con los Pizarro, Almagro y otros (AGI, 1543, signatura Patronato, 185, R. 38).

Antonio de Mendoza, virrey de México: servicios de los indios (AGI, circa 1544, signatura Patronato, 189, R. 70).

Bartolomé de las Casas: vulneración dignidad episcopal (AGI, 1545, signatura Patronato, 252, R. 10).

Carta de Fray Bartolomé de las Casas, Obispo de Chiapa, al principe Felipe, quejándose de la Audiencia de los Confines (AHNE, 1545, noviembre 9, Gracias a Dios, signatura Diversos-Colecciones, 23, N. 3). "Carta de Pedro de Gante sobre el servicio personal de indios”(AHNE, 1552, febrero 15, San Francisco de México, signatura Diversos-colecciones, 23, N. 59).

Conversión, vejaciones y trabajos de indios: Nueva Granada (AGI, 1584, signatura Patronato, 231, N. 6, R. 5).

DE LAS CASAS, Bartolomé, Conclusiones sumarias sobre el remedio de las Indias (1542, Madrid, ed. facsímil, 1992).

Fray Bartolomé de las Casas: libertad de los indios: Guatemala (AGI, Probable 1549, signatura Patronato, 252, R. 9).

${ }^{117}$ Traslosheros, Jorge, El tribunal eclesiástico, cit. (n. 101), p. 493.

${ }^{118}$ DE ZABALLA, Ana, Reflexiones en torno a la recepción del derecho eclesiástico por los indígenas de la Nueva España (pp. 45-68), en DE Zaballa BeAsCoecheA, Ana (ed.), Los indios, el derecho canónico y la justicia eclesiástica en la América Hispana virreinal (Madrid, Iberoamericana, 2010), pp. 45-47; 50 .

${ }^{119}$ Como explica Jorge Traslosheros, había que moderar el derecho con los indios y mostrarles un trato benevolente por ser el indio "cristiano nuevo de miserable condición". TrasLOSHEROS, Jorge, Los indios, el derecho canónico y la justicia eclesiástica: las razones y el drama de una historia, en DE ZABAlla BEASCOECHEA, Ana (ed.), Los indios, el derecho canónico y la justicia eclesiástica en la América Hispana virreinal (Madrid, Iberoamericana, 2010), pp. 11-25, esp. p. 18. 
Ordenanzas para los indios encomendados (AGI, 1518, diciembre, 19, Zaragoza, signatura Indiferente, 419, L. 7, f. 815v-825v).

Queja del obispo de Nicaragua de la Audiencia de los Confines (AHNE, 1545, octubre 25, Gracias a Dios, signatura Diversos-Colecciones, 23, N. 2).

Repartimientos de los servicios personales de indios (AHNE, 1549, junio 10, San Juan de Huastepec, signatura Diversos-Colecciones, 23, N. 31).

Requerimiento obispo de Chiapa sobre limites de su autoridad (AHNE, 1545, octubre 22, Gracias a Dios, signatura Diversos-Colecciones, 23, N. 1).

\section{Literatura}

Assadourian, Carlos, Fray Bartolomé de las Casas obispo: la naturaleza miserable de las naciones indianas y el derecho de la Iglesia. Un escrito de 1545, en Historia Mexicana, Colegio de México, 40/3 (1991), pp. 387-451.

CaSTAÑEDA, Paulino, La condición miserable del indio y sus privilegios, en Anuario de Estudios Americanos, 28 (1971), pp. 245-335.

CeBreiros, Eduardo, La condición jurídica de los indios y el derecho común: un ejemplo del "favor protectionis", en Condorelli, Orazio (ed. lit.), "Panta rei": Studi dedicati a Manlio Bellomo (Roma, Il Cigno Edizioni, 2004), pp. 469-489.

CUENA, Francisco, Utilización pragmática del derecho romano en dos memoriales indianos del siglo XVII sobre el protector de indios, en REHJ., 20 (1998), pp. 107-142.

- Especialidades procesales de los indios y su sustrato romanistico, en Anuario da Facultade de Dereito de Universidade A Coruña, 11 (2007), pp. 157-167.

CuniLl, Caroline, El indio miserable: nacimiento de la teoría legal en la América colonial del siglo XVI, en Cuadernos Inter.c.a.mbio, 9 (2011), pp. 229-248.

DE la Guardia, Miguel, Las leyes de Indias (Madrid, Establecimiento Tipográfico de Pedro Núñez, 1889), I.

De la Puente, José, Encomienda y encomenderos en el Perú (Sevilla, Dialpa, 1992).

DE LAS CASAS, Bartolomé, De regia potestate o derecho de autodeterminación (Madrid, Consejo Superior de Investigaciones Científicas, 1969).

- Historia de las Indias (1552, Fondo de Cultura Económica, México, 1986).

-Proclama a los feligreses de Chiapa, en Castañeda, Paulino et al. (eds.), Obras completas: 13 Cartas y Memoriales (Madrid, Alianza Editorial, 1995), pp. 193-196.

De Solórzano, Juan, Politica indiana (Madrid, Imprenta Real de la Gazeta, ed. corregida por Francisco Ramiro, 1776), II.

DE Vitoria, Francisco, De los indios, Relección primera, en Urdanoz, Teófilo (ed.), Obras de Francisco de Vitoria. Relecciones teológicas (Madrid, La Editorial Católica, 1960).

DE Zaballa, Ana, Reflexiones en torno a la recepción del derecho eclesiástico por los indigenas de la Nueva España, en DE Zaballa, Ana (ed.), Los indios, el derecho canónico y la justicia eclesiástica en la América Hispana virreinal (Madrid, Iberoamericana (2010), pp. 45-68.

Duve, Thomas, Algunas observaciones acerca del modus operandi y la prudencia del juez en el derecho canónico, en Revista de Historia del Derecho, 35 (2007), pp. 195-226.

Dumont, Jean, El amanecer de los derechos del hombre: La controversia de Valladolid (Madrid, trad. cast., María José Antón, Ediciones Encuentro, 2009).

Hanke, Lewis, Spanish Struggle for Justice (Boston, Little, Brown and Company, 1965).

Helmholz, R. H., The Spirit of Classical Canon Law (Athens, Georgia; The University of Georgia Press, 1996). 
LeVAGGI, Abelardo, La protección de los naturales por el Estado Argentino (1810-1950): el problema de la capacidad, en Revista Chilena de Historia del Derecho, 16 (1990), pp. 445-469.

PÉrez, Isacio, Autenticidad, sentido histórico y valor capital de este documento (comentario a las Conclusiones sumarias sobre el remedio de las Indias de fray Bartolomé de las Casas, 1542).

SÁnCHEZ-Concha, Rafael, De la miserable condición de los indios a las reducciones, en Del régimen hispánico. Estudios sobre la conquista y el orden virreinal peruano (San Pablo, Universidad Católica San Pablo, 2013), pp. 165-178.

Traslosheros, Jorge, El tribunal eclesiástico y los indios en el arzobispado de México, hasta 1630, en Revista Historia Mexicana, El Colegio de México, 51/3 (2002), pp. 485-516.

- Los indios, el derecho canónico y la justicia eclesiástica: las razones y el drama de una historia, en DE ZaBALla, Ana (ed.), Los indios, el derecho canónico y la justicia eclesiástica en la América hispana virreinal (Madrid, Iberoamericana, 2010), pp. 11-25. 